\title{
Surface Air Temperature Fluctuations and Lapse Rates on Olivares Gamma Glacier, Rio Olivares Basin, Central Chile, from a Novel Meteorological Sensor Network
}

\author{
Edward Hanna, ${ }^{1}$ Sebastian H. Mernild, ${ }^{2,3,4}$ Jacob C. Yde, ${ }^{4}$ and Simon de Villiers ${ }^{4}$ \\ ${ }^{1}$ School of Geography, University of Lincoln, Lincoln, UK \\ ${ }^{2}$ Nansen Environmental and Remote Sensing Center, Bergen, Norway \\ ${ }^{3}$ Antarctic and Sub-Antarctic Program, Universidad de Magallanes, Punta Arenas, Chile \\ ${ }^{4}$ Faculty of Engineering and Science, Western Norway University of Applied Sciences, Sogndal, Norway
}

Correspondence should be addressed to Sebastian H. Mernild; sebastian.mernild@nersc.no

Received 2 March 2017; Accepted 8 June 2017; Published 18 July 2017

Academic Editor: Stefania Bonafoni

Copyright (C) 2017 Edward Hanna et al. This is an open access article distributed under the Creative Commons Attribution License, which permits unrestricted use, distribution, and reproduction in any medium, provided the original work is properly cited.

\begin{abstract}
Empirically based studies of glacier meteorology, especially for the Southern Hemisphere, are relatively sparse in the literature. Here, we use an innovative network of highly portable, low-cost thermometers to report on high-frequency (1-min time resolution) surface air temperature fluctuations and lapse rates (LR) in a $~ 800-\mathrm{m}$ elevational range (from 3,675 to 4,492 $\mathrm{m}$ a.s.l.) across the glacier Olivares Gamma in the central Andes, Chile. Temperatures were measured during an intense field campaign in late Southern summer, 19-27 March 2015, under varying weather conditions. We found a complex dependence of high-frequency LR on time of day, topography, and wider meteorological conditions, with hourly temperature variations during this week that were probably mainly associated with short- and long-wave radiation changes and not with wind speed/direction changes. Using various pairs of sites within our station network, we also analyze spatial variations in LR. Uniquely in this study, we compare temperatures measured at heights of 1-m and 2-m above the glacier surface for the network of five sites and found that temperatures at these two heights occasionally differed by more than $\pm 4^{\circ} \mathrm{C}$ during the early afternoons, although the mean temperature difference is much smaller $\left(\sim 0.3^{\circ} \mathrm{C}\right)$. An implication of our results is that daily, hourly, or even monthly averaged LR may be insufficient for feeding into accurate melt models of glacier change, with the adoption of subhourly (ideally 1-10-min) resolution LR likely to prove fruitful in developing new innovative high-time-resolution melt modelling. Our results are potentially useful as input LR for local glacier melt models and for improving the understanding of lapse rate fluctuations and glacier response to climate change.
\end{abstract}

\section{Introduction}

In recent decades, land-terminating glaciers and ice caps have thinned and receded in many regions of the world including Chile (e.g., [1-6]). This is a visible response to climate variability and climate change, or more specifically changes in precipitation/snow accumulation and atmospheric warming. Glaciers in Central Chile in the central dry Andes have shrunk and retreated rapidly during the last few decades due to a warming climate [7-9], with serious impacts on water resources including drinking water and water for irrigation purposes, hydroelectric power, and future global and regional sea-level rise [10]. In Central Chile the most notable feature of the changing climate from 1979 to 2006 was a strong contrast between the coastal region (surface cooling: $-0.2^{\circ} \mathrm{C}$ decade ${ }^{-1}$ ) and the Andes region (surface warming: $0.25^{\circ} \mathrm{C}$ decade $^{-1}$ ) $[9,11]$.

From a hydrological perspective glaciers are a reservoir of freshwater stored as ice, affecting water balance conditions (e.g., [5]). In the central part of Chile (taken as the region between 30 and $38^{\circ} \mathrm{S}$ ), hydrological and climatological research studies highlight a lack of information on glaciological mass-balance observations and processes [2, 12-14]; yet such knowledge is crucial for understanding the role of glaciers in current climate and hydrological perspectives. In a generally warming climate, the annual glacier runoff 
will ultimately decline as reduced glacier area outweighs the effect of increased glacier melting [15]. According to the World Glacier Monitoring Service (WGMS) (the organization maintaining and collecting information about glacier mass-balance observations globally), few glaciers in South America have meteorological and mass-balance observations for recent decades [16, 17], and this implies a fundamental lack of understanding of climatological and glaciological conditions in complex high mountain terrain.

High-frequency observed surface air temperature lapse rates (LR) on glaciers and in complex terrain are seldom reported. Lundquist and Cayan [18] analyzed surface temperature patterns in complex terrain in Sierra Nevada, indicating that a simple lapse rate often gives a poor description of a high-frequency spatial temperature structure. Blandford et al. [19] evaluated daily and seasonal variations of surface air temperature LR in southcentral Idaho emphasizing high variability on both daily and seasonal timescales. According to Minder et al. [20], high-resolution gridding of climate data often relies on assumptions such as a constant surface temperature lapse rate of $-6.5^{\circ} \mathrm{C} \mathrm{km}^{-1}$, ignoring highfrequency fluctuations in LR. This may have consequences for numerical weather prediction models when forecasting surface air temperatures and LR in complex terrains mainly during the winter season [21]. It may also have implications for understanding the impacts from inversion and Foehn effects in these terrains. Therefore, many snow and glacier surface melt models use an assumed linear LR, for example, on mean monthly or annual timescales, to distribute nearsurface air temperature observations from automatic weather stations to locations at different elevations where meteorological observations are not available (e.g., [22]).

The present study arises from a four-year-long Fondecyt project using a multidisciplinary approach for the Rio Olivares basin, Central Chile, to significantly improve our overall understanding of meteorological, glaciological, and hydrological conditions. One of the aims of the project is to observe and analyze high-frequency near-surface air temperature fluctuations and conditions (not free-air lapse rates), including LR on Olivares Gamma Glacier [near-surface lapse rates are more variable than free-air lapse rates [23]]. This feeds into further aims to develop and set up meteorological, glacier surface mass-balance (SMB), and freshwater runoff models to determine the impact of high-frequent fluctuations in surface air temperature LR and of climate change upon glacier SMB and spatiotemporal freshwater runoff conditions under present day climate change conditions. The present work on glacier micrometeorology, together with improved models of meteorological and glacier SMB, will allow us to better understand the impacts from present climate conditions on glaciological and hydrological conditions in Central Chile and the complex interactions between these elements.

\section{Study Site}

The Olivares Gamma Glacier $\left(11.5 \mathrm{~km}^{2}\right.$ in $2012 ; 33^{\circ} 07^{\prime} \mathrm{S}$, $70^{\circ} 10^{\prime} \mathrm{W}$ ) (Figure 1) is located in the Rio Olivares basin $\left(548 \mathrm{~km}^{2}\right)$, in Central Chile, $c a .50 \mathrm{~km}$ northeast of Santiago

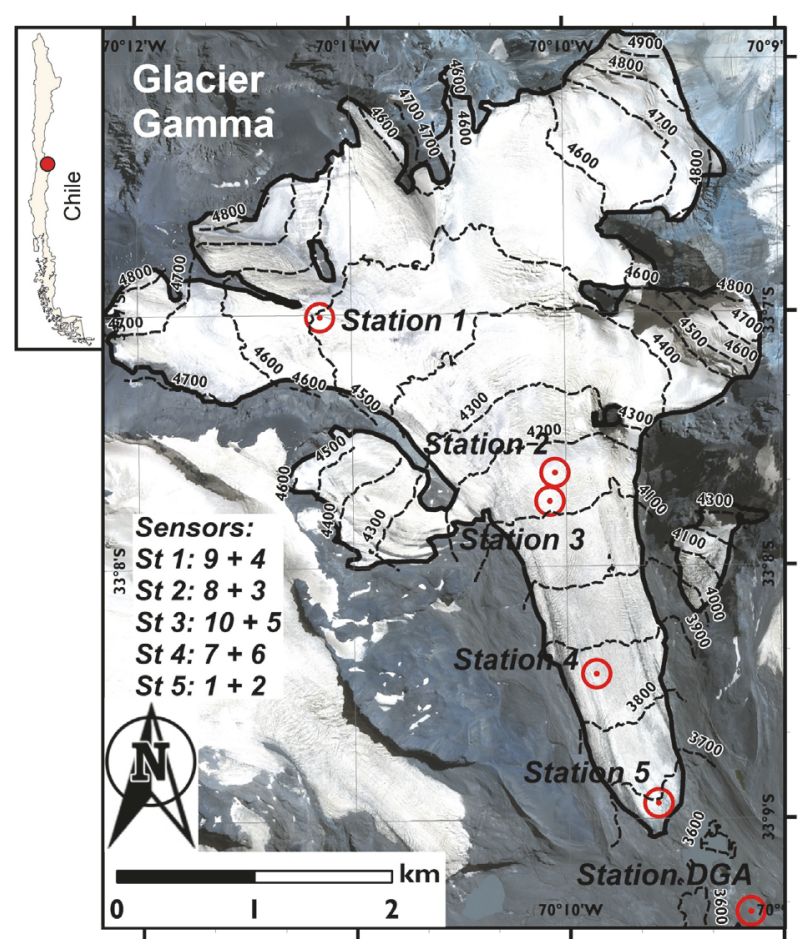

Figure 1: Location of Olivares Gamma Glacier and of meteorological stations used in the study. Topographic details of stations are given in Table 1; numbers 1-10 after the colons refer to Tinytag sensor IDs.

de Chile, the capital city of Chile (7-8 mill. inhabitants). The Rio Olivares basin contains $c a$. a quarter of all the glacierised area feeding into the Rio Maipo basin, which provides water to Santiago de Chile and a substantial part of the Central Valley. The Olivares Gamma Glacier (hereafter referred to as Gamma) is a temperate glacier with a maximum thickness of $183 \mathrm{~m}$ water equivalent (w.e.) and an estimated water volume of $0.62 \mathrm{~km}^{3}$ w.e. [24]. Gamma extends from 3,650 to $4,800 \mathrm{~m}$ a.s.l. and is facing south (Figure 1) [5]. No debriscovered glacier ice is present at Gamma. The glacier surface is characterised by fields of penitentes (ice pinnacles formed by evaporation-melt processes on high-altitude, low-latitude glaciers), generally less than $0.5 \mathrm{~m}$ in height.

\section{Methods}

We used ten Tinytag sensors, model Tinytag Plus 2 = TGP4017, deployed in small plastic radiation shields (model no. ACS-5050) mounted on individual stakes, with sensors placed at 1-m and 2-m height above the glacier surface at each site. The relatively low cost of a Tinytag temperature sensor, in comparison to an automatic weather station, meant that it was practicable to deploy ten Tinytags at five sites across the glacier (Figure 1). The equipment setup for two stations is shown in Figure 2. Station locations spanned an elevational range of $\sim 800 \mathrm{~m}$, which covered most of the glacier (Figure 1); elevation, slope, aspect, sensor ID numbers, and observation times are given in Table 1. These temperature loggers can store 
TABLE 1: Tinytag air temperature stations on Olivares Gamma Glacier. The surface elevation, slope, and aspect are obtained from the SRTM (Shuttle Radar Topography Mission), February 2000.

\begin{tabular}{|c|c|c|c|c|c|c|c|c|c|c|}
\hline Station ID & $\begin{array}{c}\text { Grid, } \\
\text { UTM } \\
\text { Zone } 19 \mathrm{H}\end{array}$ & Grid & $\begin{array}{c}\text { Elevation } \\
\text { (m a.s.l.) }\end{array}$ & $\begin{array}{l}\text { Slope SRTM } \\
\text { (degree) }\end{array}$ & $\begin{array}{l}\text { Aspect SRTM } \\
\text { (degree) }\end{array}$ & $\begin{array}{l}\text { Sensor ID, } \\
\text { 1-m above } \\
\text { surface }\end{array}$ & $\begin{array}{l}\text { Sensor ID, } \\
\text { 2-m above } \\
\text { surface }\end{array}$ & $\begin{array}{c}\text { Observed } \\
\text { time period, } \\
\text { begin (UTM } \\
\text { time) }\end{array}$ & $\begin{array}{l}\text { Observed } \\
\text { time period, } \\
\text { end (UTM } \\
\text { time) }\end{array}$ & $\begin{array}{c}\text { Sampling } \\
\text { interval }\end{array}$ \\
\hline Station 1 & 389375 & 6335136 & 4,492 & 7.8 & 127 (SE) & S9 & S4 & $19 / 3 ; 4: 00 \mathrm{pm}$ & $27 / 3 ; 10: 00 \mathrm{am}$ & $\begin{array}{l}\text { Every } \\
\text { minute }\end{array}$ \\
\hline Station 2 & 391092 & 6334010 & 4,193 & 7.2 & $171(S)$ & S8 & S3 & $19 / 3 ; 4: 40 \mathrm{pm}$ & $27 / 3 ; 10: 00 \mathrm{am}$ & $\begin{array}{l}\text { Every } \\
\text { minute }\end{array}$ \\
\hline Station 3 & 391056 & 6333803 & 4,118 & 10.4 & $168(S)$ & S10 & S5 & $19 / 3 ; 5: 30 \mathrm{pm}$ & $27 / 3 ; 10: 00 \mathrm{am}$ & $\begin{array}{l}\text { Every } \\
\text { minute }\end{array}$ \\
\hline Station 4 & 391397 & 6332541 & 3,852 & 9.0 & $163(S)$ & S7 & S6 & $20 / 3 ; 12: 15 \mathrm{pm}$ & $27 / 3 ; 10: 00 \mathrm{am}$ & $\begin{array}{l}\text { Every } \\
\text { minute }\end{array}$ \\
\hline Station 5 & 391848 & 6331598 & 3,675 & 7.4 & $163(S)$ & S1 & S2 & $21 / 3 ; 4: 50 \mathrm{pm}$ & $27 / 3 ; 10: 00 \mathrm{am}$ & $\begin{array}{l}\text { Every } \\
\text { minute }\end{array}$ \\
\hline
\end{tabular}

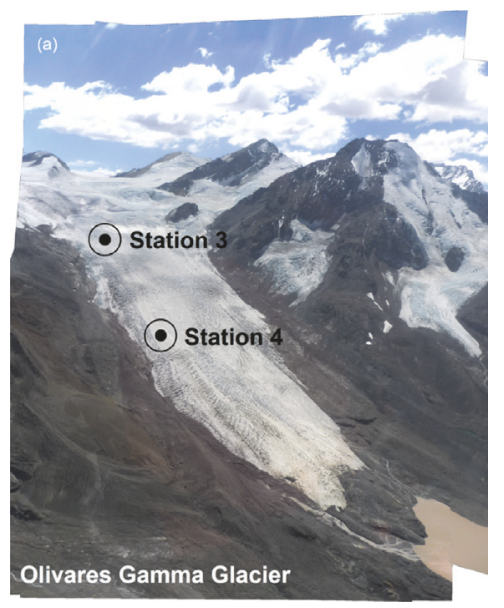

(a)

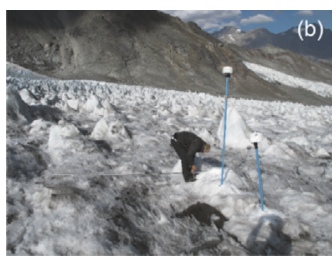

(b)

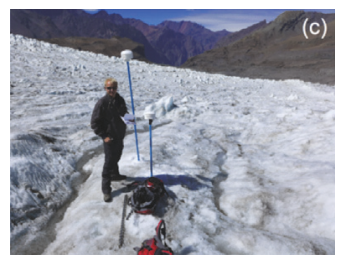

(c)

Figure 2: (a) Photos of Olivares Gamma Glacier taken from drone looking north [the distance between Stations 3 and 4 is approximately one kilometre]; (b) Station 3 at 4,118-m elevation with Tinytag sensors 10 and 5 at $1 \mathrm{~m}$ and $2 \mathrm{~m}$ heights; (c) Station 4 at 3,852-m elevation with Tinytag sensors 7 and 6 at $1 \mathrm{~m}$ and $2 \mathrm{~m}$ heights. Photo (a) was stitched together and (b) was taken by J. C. Yde and (c) by E. Hanna.

up to 32,000 readings and are suitable for deployment in the field for 6-12 months; they have successfully been deployed in the sub-Arctic in previous studies (e.g., [25]).

Temperatures were logged at 1-min intervals, loggers were synchronised before deployment in the field, and all times reported in this paper are GMT/UTC (during the Austral, summer Chile is GMT -4 hours). Before being used in the field, the Tinytags were calibrated and validated against a full United Kingdom Accreditation Service (UKAS) Calibrated Max Min Thermometer, which had been calibrated to national standards using an independent calibration laboratory and was supplied with a traceable three-point calibration certificate taken at $0^{\circ} \mathrm{C}, 10^{\circ} \mathrm{C}$, and $25^{\circ} \mathrm{C}$ full UKAS standards and a cited accuracy of $0.1^{\circ} \mathrm{C}$. Over a $15^{\circ} \mathrm{C}$ temperature range, the Tinytags agreed on average to within $+0.1-0.4^{\circ} \mathrm{C}$ of the reference thermometer, with a mean difference of $+0.2^{\circ} \mathrm{C}$. These combined accuracies are within the Tinytag manufacturer's quoted accuracy of $\pm 0.5^{\circ} \mathrm{C}$ for a $0-20^{\circ} \mathrm{C}$ temperature range.
We also used a supplementary LogTag TRIX-8 Temperature Recorder in each screen, which automatically logged air temperature at 2-min intervals, to support the main temperature dataset. The LogTags store a slightly lower number of readings $(8,000$; hence the lower time resolution used here) but are considered by the manufacturer to be accurate to $\pm 0.5^{\circ} \mathrm{C}$ for $-20^{\circ} \mathrm{C}$ to $+40^{\circ} \mathrm{C}$, that is, similar to the quoted accuracy of the Tinytags.

The Tinytag and LogTag temperature data were supplemented by an automatic weather station (AWS) (Station DGA) located at 3,631-m elevation in the proglacial landscape in front of the glacier (Figure 1). This provided hourly readings not just of air temperature but also of relative humidity, barometric pressure, wind speed and direction, and incoming/outgoing short- and long-wave radiation, which helped place our distributed air temperature records in a wider meteorological context.

We use standard descriptive statistics and correlation analysis to summarise observational results and compare key 


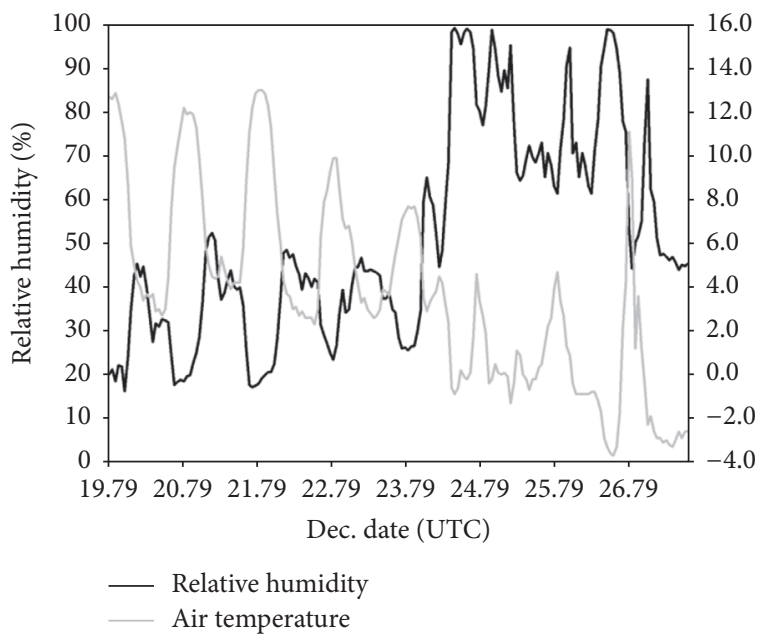

(a)

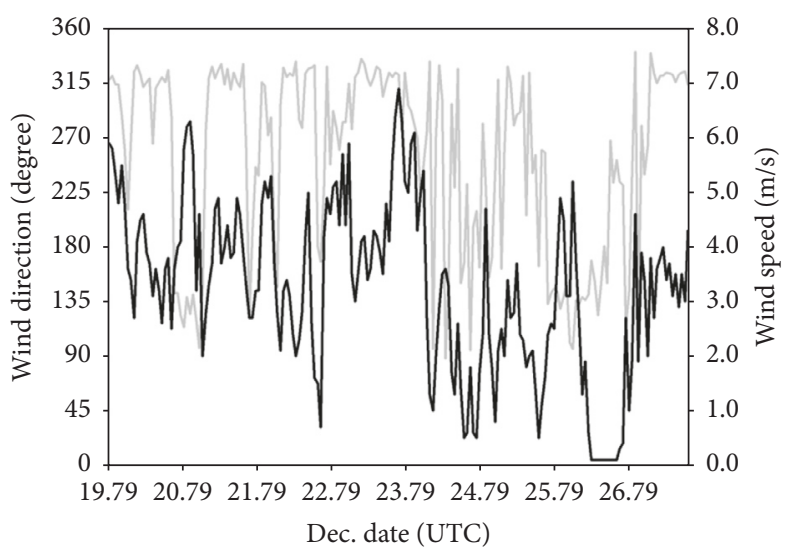

Wind direction
- Wind speed

(c)

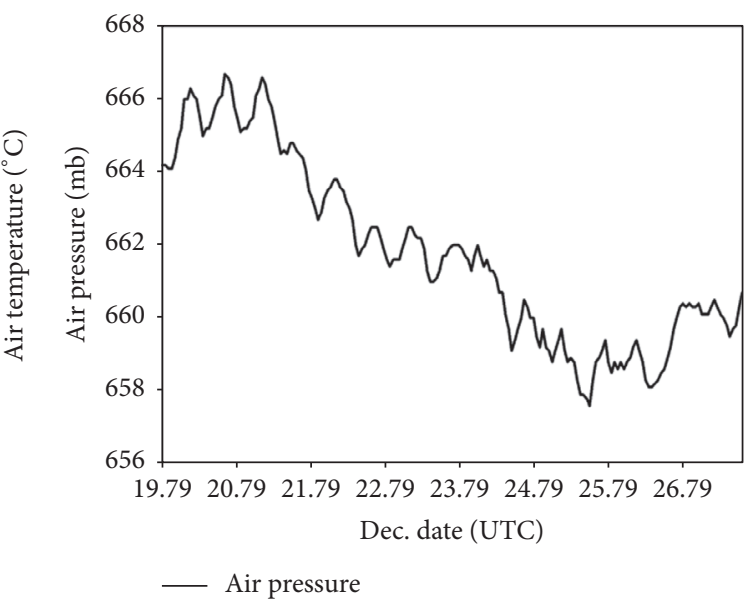

(b)

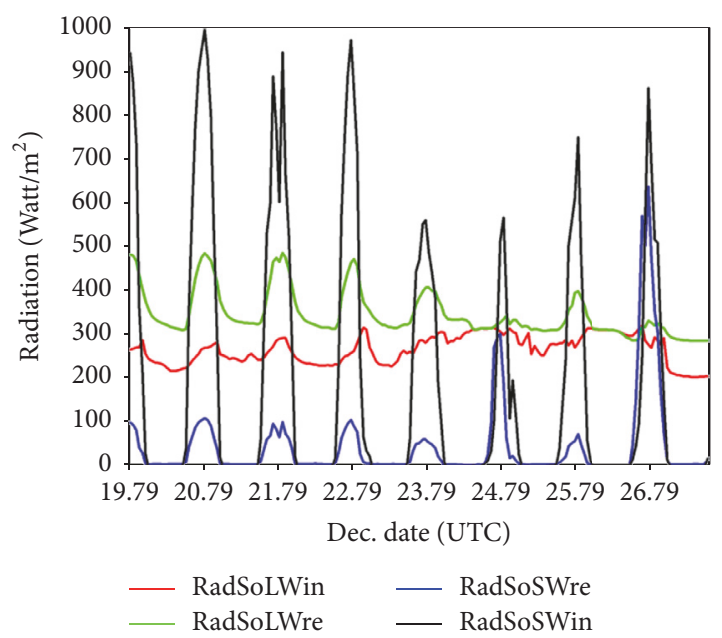

(d)

FIGURE 3: DGA automatic weather station time series from 19 March to 26 March 2015: (a) surface air temperature and relative humidity; (b) mean sea-level pressure; (c) wind speed and wind direction; and (d) incoming (black) and reflected (blue) shortwave radiation, and incoming (red) and outgoing (green) long-wave radiation.

datasets. Lapse rates are expressed as negative when temperatures decrease with height and positive when temperatures increase with height.

\section{Results and Discussion}

4.1. General Weather Conditions. Figure 3(a) shows the meteorological data recorded at DGA during the fieldwork campaign. Daily temperatures ranged from $\sim 3-4^{\circ} \mathrm{C}$ (during night) to $\sim 12-13^{\circ} \mathrm{C}$ (during day) during the first few days then declined to $-3-0^{\circ} \mathrm{C}$ to $\sim 4-10^{\circ} \mathrm{C}$ during the latter part of the campaign. These temperature changes were mirrored by opposite changes in relative humidity $(\mathrm{RH})$ to near-saturated air masses ( $70-100 \% \mathrm{RH})$ during the latter half of the period, with RH having risen from a relatively dry air mass of $20-50 \%$ saturation during the first few days (Figure 3(a)). Surface air pressure dropped from $\sim 666 \mathrm{hPa}$ in the first two days to $\sim 658-662 \mathrm{hPa}$ in the days thereafter, reaching a minimum of
$<658 \mathrm{hPa}$ on $25 \mathrm{March}$ (Figure 3(b)). Winds were generally fairly light $\left(\sim 1-6 \mathrm{~m} \mathrm{~s}^{-1}\right.$ for 10-min averages) and the wind was predominantly northwesterly during the first half of the period, turning more variable and mainly to a southerly point afterwards (Figure 3(c)). Incoming solar radiation peaked at between 700 and $900 \mathrm{~W} \mathrm{~m}^{-2}$ during the first half of the period, with relatively low peaks around $500-600 \mathrm{~W} \mathrm{~m}^{-2}$ on 23 and 24 March. Long-wave radiation, both incoming and outgoing, varied most during the first few days, reflecting clearer skies, stronger surface heating during daylight hours, and greater heat loss in night time (Figure 3(d)).

4.2. Glacier Near-Surface Hourly Temperatures and Lapse Rates and Comparison with DGA Meteorological Data. A comparison of DGA hourly surface air temperature with 2$\mathrm{m}$ temperatures at the five Tinytag sites is shown in Figure 4. Figure 4(a) confirms a steady temperature decrease at all sites throughout the week-long period. DGA daytime peaks 


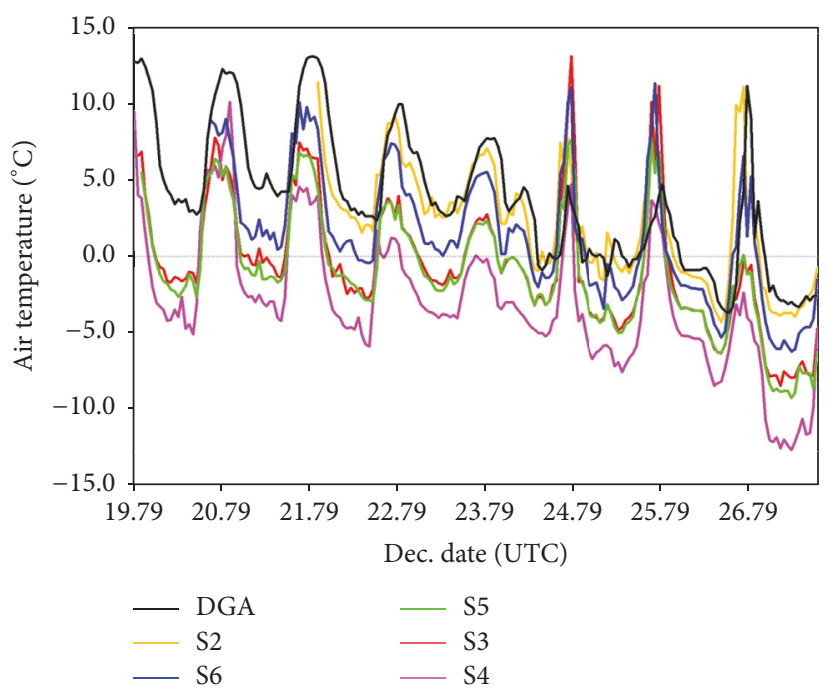

(a)

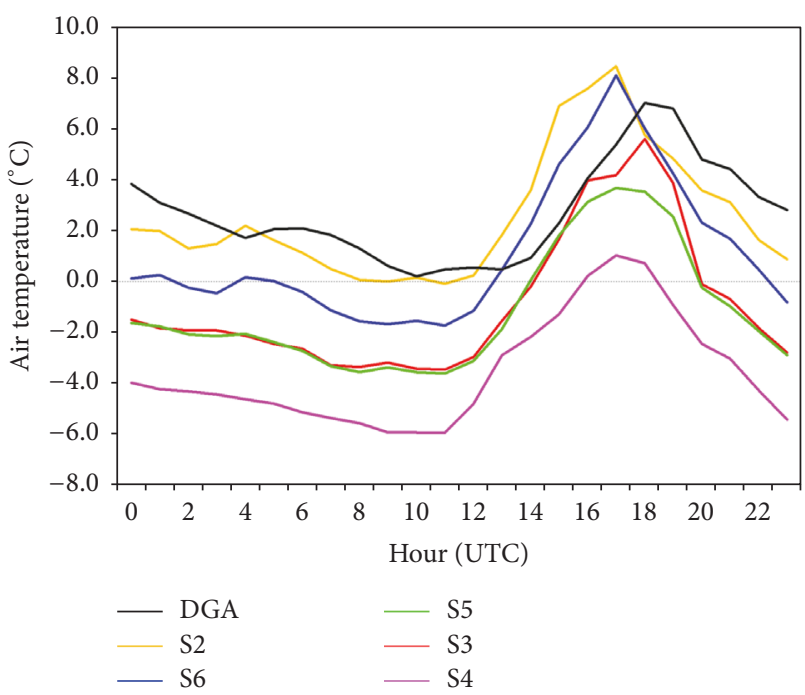

(b)

FIGURE 4: (a) 2-m surface air temperature profiles at the DGA automatic weather station and Tinytag sensors S2, S6, S5, S3, and S4 (moving progressively up the glacier), based on data recorded each hour (19-26 March 2015); and (b) mean daily 2-m surface air temperature profiles (22-26 March 2015) for the same stations/sensors as in Figure 4(a).

tended to occur 1-2 hours after temperature peaks at the Tinytag sites (Figure 4(b)). Mean hourly temperatures data for the DGA and Tinytag sites for 22-26 March 2015 are shown in Table 2 and Figure 4(b). DGA temperature ranged from $0.2^{\circ} \mathrm{C}$ at $10: 00$ to $7.0^{\circ} \mathrm{C}$ at 18:00; the nearest Tinytag 2$\mathrm{m}$ Station S2 ranged from $-0.1^{\circ} \mathrm{C}$ at $11: 00$ to $8.5^{\circ} \mathrm{C}$ at $17: 00$. At 11:00, on average, 2-m temperatures at five out of six sites were below freezing (except for DGA $=0.5^{\circ} \mathrm{C}$ ). Overall, mean hourly temperatures (mean of all 24 hours) for these five days were similar at $2.7^{\circ} \mathrm{C}$ and $2.5^{\circ} \mathrm{C}$ for DGA and S2, although temperature variations were greater at $\mathrm{S} 2$, with a standard deviation of $2.5^{\circ} \mathrm{C}$ for all hourly data compared with $1.9^{\circ} \mathrm{C}$ at DGA. Mean hourly temperatures at the highest site S4 $(4,492 \mathrm{~m})$ were only slightly above freezing $\left(0.2-1.0^{\circ} \mathrm{C}\right)$ at three hours, 16:00-18:00, compared with 23 hours for the lowest Tinytag site S2 and all hours at DGA (Figure 4(b)). This suggests that there was not much melting on the upper reaches of the glacier around Station 1 (S9/S4) during the study period. However, mean daily $2-\mathrm{m}$ temperatures were above freezing $\left(1.1^{\circ} \mathrm{C}\right.$ at $\mathrm{S} 6$ and $2.5^{\circ} \mathrm{C}$ at $\left.\mathrm{S} 2\right)$ for the lowest two Tinytag stations. The highest mean hourly temperatures (at $17: 00$ ) of $8.5^{\circ} \mathrm{C}$ and $8.1^{\circ} \mathrm{C}$ at the same two sites were substantially above the mean hourly temperature of $5.4^{\circ} \mathrm{C}$ at the lower DGA site (which occupies much darker moraine and bedrock well below the glacier terminus). This could be due to strong reflected solar radiation enhancing surface air temperature readings (even though they were obtained from properly screened thermometers) at the Tinytag sites.

Mean hourly (22-26 March 2015) lapse rate data for various pairs of 2-m sensors are given in Table 3. In that table, the second from left column LR (S4-S2) shows the full-range lapse rate between the 2-m Tinytags at Stations 1 and 5, which are separated by $817 \mathrm{~m}$ in elevation (Figure 1; Table 1). This shows the strongest lapse rates, commonly $<-10.0^{\circ} \mathrm{C} \mathrm{km}^{-1}$, during the early afternoon hours, with hourly lapse rates generally between about -7 and $-8^{\circ} \mathrm{C} \mathrm{km}^{-1}$ at other times. Therefore, these lapse rates were mainly slightly smaller than the dry adiabatic lapse rate (DALR) of $-9.8^{\circ} \mathrm{C} \mathrm{km}^{-1}$, and it was only at 15:00 that the DALR was on average exceeded (greater negative values). These super-adiabatic lapse rates could be due to preferential warming of lower slopes under conditions there of greater ice-melt and lower albedo, hence more absorption of incoming solar radiation. Subprofiles between pairs of stations reveal occasional much stronger mean hourly lapse rates, for example, $-16.6^{\circ} \mathrm{C} \mathrm{km}^{-1}$ for S5S6 (Stations 3 and 4) at 17:00 and $-13.0^{\circ} \mathrm{C} \mathrm{km}^{-1}$ for S6-S2 (Stations 4 and 5) at 15:00 for the six days. Large reductions (smaller negative values) in lapse rates at some sites were evident for the mid-afternoon hours. These include most notably reductions in the S3-S2 (Stations 2-5) lapse rate from $-10.1^{\circ} \mathrm{C} \mathrm{km}^{-1}$ at $15: 00$ to $-0.3^{\circ} \mathrm{C} \mathrm{km}^{-1}$ at $18: 00$, the $\mathrm{S} 3-\mathrm{S} 6$ (Stations 2-4) lapse rate from $-11.5^{\circ} \mathrm{C} \mathrm{km}^{-1}$ at $17: 00$ to $-1.2^{\circ} \mathrm{C}$ $\mathrm{km}^{-1}$ at 18:00, and the S6-S2 (Stations 4 and 5) lapse rate from $-13.0^{\circ} \mathrm{C} \mathrm{km}^{-1}$ at $15: 00$ to $1.5^{\circ} \mathrm{C} \mathrm{km}^{-1}$ at 18:00 (Table 3). The latter case is the only reversed (positive) lapse rate value in the whole of Table 3, where the normal lapse rate profile (temperature decrease with height) temporarily changes sign at 18:00 on average over the six days (there is another, already mentioned near-neutral lapse rate of $-0.3^{\circ} \mathrm{C} \mathrm{km}^{-1}$ for S3-S2 at the same time).

These early afternoon large drops/reversals in lapse rates are mainly related to the diurnal temperature peaking one hour later at S3 (Station 2) compared with the lower S6 (Station 4) and S2 (Station 5) - and indeed the other two S4 and S5 2-m LogTags-sites; the only other site with peak temperature at 18:00 (in common with S3/Station 2) is DGA. Why do these two sites' daily temperatures peak later than the others? There is nothing especially unusual about the slope and aspect of Station 2 compared with the other four stations 
TABle 2: Comparison of surface air temperature $\left({ }^{\circ} \mathrm{C}\right)$ mean hourly data for 22-26 March 2015 at DGA and the five Tinytag sites $(2-\mathrm{m}$ sensors). See Figure 1 and Table 1 for site details. Hours with nocturnal observations are highlighted in italic (https://www.timeanddate.com/ sun/chile/santiago), here illustrated in UTC.

\begin{tabular}{|c|c|c|c|c|c|c|}
\hline Hour (UTC) & DGA & S2 & S6 & S5 & S3 & $\mathrm{S} 4$ \\
\hline 0 & 3.8 & 2.1 & 0.1 & -1.6 & -1.5 & -4.0 \\
\hline 1 & 3.1 & 2.0 & 0.3 & -1.8 & -1.8 & -4.2 \\
\hline 2 & 2.7 & 1.3 & -0.2 & -2.1 & -1.9 & -4.3 \\
\hline 3 & 2.2 & 1.5 & -0.5 & -2.1 & -1.9 & -4.4 \\
\hline 4 & 1.7 & 2.2 & 0.2 & -2.0 & -2.1 & -4.6 \\
\hline 5 & 2.1 & 1.6 & 0.0 & -2.4 & -2.4 & -4.8 \\
\hline 6 & 2.1 & 1.1 & -0.4 & -2.7 & -2.6 & -5.1 \\
\hline 7 & 1.8 & 0.5 & -1.1 & -3.3 & -3.3 & -5.4 \\
\hline 8 & 1.3 & 0.1 & -1.5 & -3.5 & -3.3 & -5.5 \\
\hline 9 & 0.6 & 0.0 & -1.7 & -3.4 & -3.2 & -5.9 \\
\hline 10 & 0.2 & 0.2 & -1.5 & -3.6 & -3.4 & -5.9 \\
\hline 11 & 0.5 & -0.1 & -1.7 & -3.6 & -3.4 & -5.9 \\
\hline 12 & 0.6 & 0.3 & -1.1 & -3.1 & -2.9 & -4.8 \\
\hline 13 & 0.5 & 1.8 & 0.5 & -1.9 & -1.5 & -2.9 \\
\hline 14 & 0.9 & 3.6 & 2.3 & 0.1 & -0.2 & -2.2 \\
\hline 15 & 2.3 & 6.9 & 4.6 & 1.8 & 1.7 & -1.3 \\
\hline 16 & 4.1 & 7.6 & 6.1 & 3.1 & 4.0 & 0.2 \\
\hline 17 & 5.4 & 8.5 & 8.1 & 3.7 & 4.2 & 1.0 \\
\hline 18 & 7.0 & 5.7 & 6.0 & 3.5 & 5.6 & 0.7 \\
\hline 19 & 6.8 & 4.8 & 4.3 & 2.6 & 3.9 & -0.9 \\
\hline 20 & 4.8 & 3.6 & 2.3 & -0.2 & -0.1 & -2.4 \\
\hline 21 & 4.4 & 3.1 & 1.7 & -1.0 & -0.7 & -3.0 \\
\hline 22 & 3.3 & 1.6 & 0.5 & -1.9 & -1.8 & -4.3 \\
\hline 23 & 2.8 & 0.9 & -0.8 & -2.9 & -2.8 & -5.4 \\
\hline Mean & 2.7 & 2.5 & 1.1 & -1.2 & -0.9 & -3.6 \\
\hline ST DEV & 1.9 & 2.5 & 2.8 & 2.4 & 2.7 & 2.1 \\
\hline
\end{tabular}

(Table 1). As is clear from Figure 1, both Stations 2 and 3 are located fairly near the mid-point/centre line of the glacier, so anomalous shading from surrounding topography at Station 2 is not an issue [especially at this time of the year/local time of day, early afternoon, when the Sun was high in the (northern) sky]. Based on site photos, for example, Figure 2(b) for Station 3, the glacier surface at Station 3 appears significantly rougher and possibly consequently darker than Station 2, so it could be that a local effect of the glaciomorphology influences the surface energy balance, and this effect may delay the timing of the peak daily temperature at Station 2. We postulate that this is because the generally smoother, brighter ice surface at Station 2 takes longer to respond to increasing solar radiation during the first half of the day. The 2-m nighttime temperatures at S3 (Station 2) and S5 (Station 3) are very similar but mid-afternoon temperatures are much higher at S3 (by over $2^{\circ} \mathrm{C}$ at 18:00, Table 2), even though they peak slightly later. These differences emphasize the importance of local glacier surface microstructure on the $1 \mathrm{~cm}$ to $10 \mathrm{~m}$ spatial scale, compared with broader-scale topography, in affecting surface air temperature daily peaks and the timings of these. Heterogeneous surface microstructure has an impact on both the spatial and temporal variability in lapse rates, as illustrated above. In agreement, Blandford et al. [19], working in mountainous regions in southcentral Idaho, showed that different synoptic weather types influenced surface lapse rates, where, for example, warmer air temperatures were associated with steeper lapse rates and vice versa.

Correlations between hourly temperature data and meteorological parameters recorded by the DGA AWS are given in Table 4. These show significant strong positive correlations between Tinytag temperatures and DGA air temperature, incoming shortwave radiation, and outgoing longwave radiation but little/insignificant correlation between Tinytag temperatures, for any of the sites, and wind speed and direction recorded at DGA. This suggests that glacier surface air temperatures during the week-long period in question were regulated mainly by key radiative components of the surface energy balance and very little by advective processes (wind). While the wind speed data recorded at DGA suggest that wind does not have an impact on lapse rate, we cannot exclude the possibility that there could be microscale advection occurring along the glacier-particularly in those short periods when lapse rates become very high for a few minutes. Some kind of upslope convection is necessary to stabilize the atmosphere along slope. Given that there are no high-frequency wind measurements along the slope of the glacier in this study, advection cannot be entirely discounted. 
TABle 3: Comparison of mean hourly lapse rate data $\left({ }^{\circ} \mathrm{C} \mathrm{km}^{-1}\right)$ for $22-26$ March 2015 at the five Tinytag sites (2-m sensors). See Figure 1 and Table 1 for site details. Hours with nocturnal observations are highlighted in italic (https://www.timeanddate.com/sun/chile/santiago), here illustrated in UTC.

\begin{tabular}{|c|c|c|c|c|c|c|c|c|c|}
\hline Hour (UTC) & LR (S4-S2) & LR (S3-S2) & LR (S5-S2) & LR (S6-S2) & LR (S4-S6) & LR (S3-S6) & LR (S5-S6) & LR (S4-S5) & LR (S4-S3) \\
\hline 0 & -7.4 & -6.8 & -8.3 & -10.9 & -6.4 & -4.7 & -6.5 & -6.3 & -8.3 \\
\hline 1 & -7.6 & -7.4 & -8.5 & -9.8 & -7.0 & -6.1 & -7.6 & -6.6 & -8.0 \\
\hline 2 & -6.9 & -6.2 & -7.6 & -8.7 & -6.4 & -4.9 & -6.9 & -6.0 & -8.0 \\
\hline 3 & -7.2 & -6.5 & -8.1 & -10.9 & -6.2 & -4.3 & -6.3 & -6.1 & -8.4 \\
\hline 4 & -8.3 & -8.3 & -9.6 & -11.4 & -7.5 & -6.7 & -8.4 & -6.9 & -8.3 \\
\hline 5 & -7.9 & -7.9 & -9.1 & -9.1 & -7.5 & -7.2 & -9.0 & -6.4 & -7.8 \\
\hline 6 & -7.7 & -7.3 & -8.7 & -8.7 & -7.4 & -6.5 & -8.7 & -6.5 & -8.3 \\
\hline 7 & -7.2 & -7.3 & -8.6 & -9.2 & -6.6 & -6.3 & -8.2 & -5.4 & -7.0 \\
\hline 8 & -6.9 & -6.6 & -8.2 & -9.2 & -6.2 & -5.3 & -7.5 & -5.3 & -7.4 \\
\hline 9 & -7.2 & -6.1 & -7.6 & -9.5 & -6.6 & -4.4 & -6.3 & -6.8 & -9.2 \\
\hline 10 & -7.4 & -6.9 & -8.4 & -9.6 & -6.8 & -5.5 & -7.6 & -6.3 & -8.3 \\
\hline 11 & -7.2 & -6.5 & -8.0 & -9.3 & -6.6 & -5.1 & -7.1 & -6.2 & -8.3 \\
\hline 12 & -6.2 & -6.2 & -7.6 & -7.8 & -5.7 & -5.3 & -7.4 & -4.5 & -6.1 \\
\hline 13 & -5.8 & -6.5 & -8.3 & -7.7 & -5.3 & -5.9 & -8.8 & -2.7 & -4.5 \\
\hline 14 & -7.0 & -7.3 & -7.9 & -7.4 & -6.9 & -7.2 & -8.3 & -5.9 & -6.6 \\
\hline 15 & -10.0 & -10.1 & -11.5 & -13.0 & -9.2 & -8.6 & -10.5 & -8.3 & -9.8 \\
\hline 16 & -9.0 & -7.0 & -10.0 & -8.6 & -9.1 & -6.1 & -11.0 & -7.8 & -12.5 \\
\hline 17 & -9.1 & -8.3 & -10.8 & -2.1 & -11.0 & -11.5 & -16.6 & -7.1 & -10.5 \\
\hline 18 & -6.2 & -0.3 & -5.0 & 1.5 & -8.3 & -1.2 & -9.3 & -7.5 & -16.3 \\
\hline 19 & -7.0 & -1.9 & -5.1 & -3.2 & -8.1 & -1.1 & -6.4 & -9.3 & -16.0 \\
\hline 20 & -7.4 & -7.1 & -8.6 & -7.1 & -7.4 & -7.1 & -9.6 & -5.9 & -7.8 \\
\hline 21 & -7.5 & -7.3 & -9.2 & -8.0 & -7.4 & -6.9 & -10.0 & -5.5 & -7.9 \\
\hline 22 & -7.2 & -6.7 & -8.1 & -6.6 & -7.4 & -6.7 & -9.1 & -6.3 & -8.2 \\
\hline 23 & -7.7 & -7.1 & -8.5 & -9.6 & -7.2 & -5.8 & -7.8 & -6.8 & -8.8 \\
\hline Mean & -7.5 & -6.6 & -8.4 & -8.2 & -7.3 & -5.9 & -8.5 & -6.4 & -8.9 \\
\hline ST DEV & 0.9 & 1.9 & 1.4 & 3.1 & 1.2 & 2.1 & 2.2 & 1.3 & 2.7 \\
\hline
\end{tabular}

TABLE 4: Correlation coefficients between surface air temperatures recorded by the Tinytags and meteorological parameters recorded at the DGA automatic weather station, based on hourly data from 21:00 on 21 March to 13:00 on 27 March 2015. Correlations $\geq 0.5$ or $\leq-0.5$ are highlighted in bold.

\begin{tabular}{ccccccccccc}
\hline & Air temp. & $\begin{array}{c}\text { Rel. } \\
\text { humidity }\end{array}$ & $\begin{array}{c}\text { Wind } \\
\text { direction }\end{array}$ & $\begin{array}{c}\text { Wind } \\
\text { speed }\end{array}$ & $\begin{array}{c}\text { Snow } \\
\text { depth }\end{array}$ & $\begin{array}{c}\text { Air } \\
\text { pressure }\end{array}$ & $\begin{array}{c}\text { Incoming } \\
\text { shortwave }\end{array}$ & $\begin{array}{c}\text { Incoming } \\
\text { long-wave }\end{array}$ & $\begin{array}{c}\text { Outgoing } \\
\text { long-wave }\end{array}$ & $\begin{array}{c}\text { Reflected } \\
\text { shortwave }\end{array}$ \\
\hline 2-m Tinytags & & & & & & & & & & \\
S2 & $\mathbf{0 . 7 8}$ & -0.43 & 0.02 & 0.30 & 0.08 & $\mathbf{0 . 5 3}$ & $\mathbf{0 . 6 1}$ & 0.16 & $\mathbf{0 . 7 1}$ & 0.39 \\
S6 & $\mathbf{0 . 7 5}$ & -0.34 & -0.09 & 0.25 & 0.09 & 0.41 & $\mathbf{0 . 6 7}$ & 0.24 & $\mathbf{0 . 7 0}$ & 0.38 \\
S5 & $\mathbf{0 . 7 1}$ & -0.24 & -0.17 & 0.19 & 0.08 & 0.34 & $\mathbf{0 . 6 2}$ & 0.35 & $\mathbf{0 . 6 9}$ & 0.28 \\
S3 & $\mathbf{0 . 6 6}$ & -0.22 & -0.17 & 0.18 & 0.08 & 0.29 & $\mathbf{0 . 6 3}$ & 0.30 & $\mathbf{0 . 6 6}$ & 0.28 \\
S4 & $\mathbf{0 . 7 1}$ & -0.25 & -0.18 & 0.21 & 0.05 & 0.35 & $\mathbf{0 . 5 9}$ & 0.36 & $\mathbf{0 . 7 0}$ & 0.24 \\
1-m Tinytags & & & & & & & & & \\
S1 & $\mathbf{0 . 7 6}$ & -0.39 & -0.01 & 0.28 & 0.05 & 0.51 & $\mathbf{0 . 6 0}$ & 0.19 & $\mathbf{0 . 6 8}$ & 0.43 \\
S7 & $\mathbf{0 . 7 2}$ & -0.28 & -0.13 & 0.21 & 0.06 & 0.38 & $\mathbf{0 . 6 4}$ & 0.29 & $\mathbf{0 . 6 7}$ & 0.39 \\
S10 & $\mathbf{0 . 6 6}$ & -0.18 & -0.21 & 0.14 & 0.06 & 0.29 & $\mathbf{0 . 6 1}$ & 0.37 & $\mathbf{0 . 6 5}$ & 0.31 \\
S8 & $\mathbf{0 . 7 0}$ & -0.24 & -0.18 & 0.20 & 0.07 & 0.32 & $\mathbf{0 . 6 6}$ & 0.33 & $\mathbf{0 . 6 9}$ & 0.32 \\
S9 & $\mathbf{0 . 6 9}$ & -0.21 & -0.21 & 0.18 & 0.05 & 0.32 & $\mathbf{0 . 5 5}$ & 0.41 & $\mathbf{0 . 6 8}$ & 0.20 \\
\hline
\end{tabular}


TABLE 5: Comparison of mean hourly 2-m minus 1-m temperature differences $\left({ }^{\circ} \mathrm{C}\right)$ for $22-26$ March 2015 at the five Tinytag sites. Differences $\geq \pm 0.5^{\circ} \mathrm{C}$ are highlighted in bold. See Figure 1 and Table 1 for site details. Hours with nocturnal observations are highlighted in italic (https://www.timeanddate.com/sun/chile/santiago), here illustrated in UTC.

\begin{tabular}{|c|c|c|c|c|c|}
\hline Hour (UTC) & S2-S1 & S6-S7 & S5-S10 & S3-S8 & S4-S9 \\
\hline 0 & 0.3 & 0.2 & 0.2 & 0.2 & 0.2 \\
\hline 1 & 0.3 & 0.3 & 0.2 & 0.2 & 0.2 \\
\hline 2 & 0.3 & 0.3 & 0.2 & 0.2 & 0.1 \\
\hline 3 & 0.4 & 0.3 & 0.1 & 0.2 & 0.2 \\
\hline 4 & 0.4 & 0.2 & 0.2 & 0.1 & 0.2 \\
\hline 5 & 0.4 & 0.3 & 0.2 & 0.3 & 0.2 \\
\hline 6 & 0.4 & 0.4 & 0.2 & 0.2 & 0.3 \\
\hline 7 & 0.3 & 0.2 & 0.2 & 0.2 & 0.3 \\
\hline 8 & 0.2 & 0.2 & 0.2 & 0.3 & 0.2 \\
\hline 9 & 0.3 & 0.2 & 0.2 & 0.1 & 0.2 \\
\hline 10 & 0.3 & 0.3 & 0.3 & 0.2 & 0.2 \\
\hline 11 & 0.3 & 0.2 & 0.3 & 0.2 & 0.2 \\
\hline 12 & 0.3 & 0.3 & 0.2 & 0.1 & 0.3 \\
\hline 13 & 0.3 & 0.7 & 0.3 & -0.1 & 0.1 \\
\hline 14 & 0.4 & 0.6 & 0.1 & -0.5 & 0.3 \\
\hline 15 & 0.4 & 0.3 & -0.4 & -0.4 & 0.4 \\
\hline 16 & 0.1 & -0.1 & -0.7 & 0.3 & 0.7 \\
\hline 17 & 0.1 & 0.6 & -0.7 & 0.1 & 0.9 \\
\hline 18 & 0.5 & 1.3 & -0.7 & 1.1 & 1.1 \\
\hline 19 & 0.5 & 0.3 & -0.1 & 1.0 & 0.7 \\
\hline 20 & 0.4 & 0.6 & 0.1 & -0.2 & 0.5 \\
\hline 21 & 0.4 & 0.4 & 0.1 & 0.1 & 0.1 \\
\hline 22 & 0.2 & 0.5 & 0.1 & 0.0 & 0.1 \\
\hline 23 & 0.2 & 0.2 & 0.2 & 0.1 & 0.3 \\
\hline Mean & 0.3 & 0.4 & 0.0 & 0.2 & 0.3 \\
\hline ST DEV & 0.1 & 0.3 & 0.3 & 0.3 & 0.3 \\
\hline
\end{tabular}

Although our findings are only for a week-long period due to practical fieldwork constraints, Pepin et al. [26] conducted a study in the uplands of northern England evaluating surface air temperature lapse rates, highlighting that steep lapse rates occurred with higher levels of solar radiation, but also that wind speed during the day had relatively little impact on lapse rates, in agreement with our results.

4.3. Comparison of Temperatures at 1-m and 2- $m$ Heights above Glacier Surface. We also compare Tinytag temperatures recorded at 2-m and 1-m heights. Differences between these are generally small $0.1-0.4^{\circ} \mathrm{C}$, but occasionally exceed $1^{\circ} \mathrm{C}$ based on mean hourly data (Table 5). Figure 5(a) shows occasional 2-1 $\mathrm{m}$ air temperature differences for individual days as great as $\pm 4^{\circ} \mathrm{C}$ based on 1-min data. For the mean daily profile, greatest differences were between 13:00 and 20:00 UTC, and briefly exceed $1.5^{\circ} \mathrm{C}$ at S6-S7 (Station 4) based on 1-min data (Figure 5(b)). Figure 5(a) shows occasional 2-1 m air temperature differences for individual days as great as $\pm 4^{\circ} \mathrm{C}$ based on 1-min data. Differences are generally negative (higher temperatures at $2 \mathrm{~m}$ ) but positive in mid-afternoon (local time) at S5-S10 and S3-S8 (Stations 2 and 3). The greatest negative differences are for S6-S7, S4-S9, and S2-S1 (Stations 4, 1, and 5) in mid-afternoon.

The generally greater temperatures at $2-\mathrm{m}$ can be attributed to boundary-layer effects of a cold ice surface having a stronger influence on suppressing air temperatures nearer the surface during daytime, especially under conditions of strong solar radiation, and heat loss through infrared radiational cooling lowering the surface temperature more during night time. The latter effect appears to have prevailed under clear night skies during the first half of the period (19-23 March 2015), as thereafter the night-time temperature bias was mainly much closer to zero (Figure 5(a)). Local site characteristics, such as albedo and topographic roughness, and/or meteorological changes, for example, localscale microadvection, may explain the opposite sign of 2$1 \mathrm{~m}$ temperature differences during mid-afternoon at Stations 2 and 3 , since temperature differences at all five sites were systematically slightly positive at other times of the day.

The good agreement of the systematic positive temperature bias from 23:00 to 12:00 supports the good relative accuracy/calibration of the Tinytags (discussed above). The 1min data also show rapid variation of $2-1 \mathrm{~m}$ vertical lapse rates 


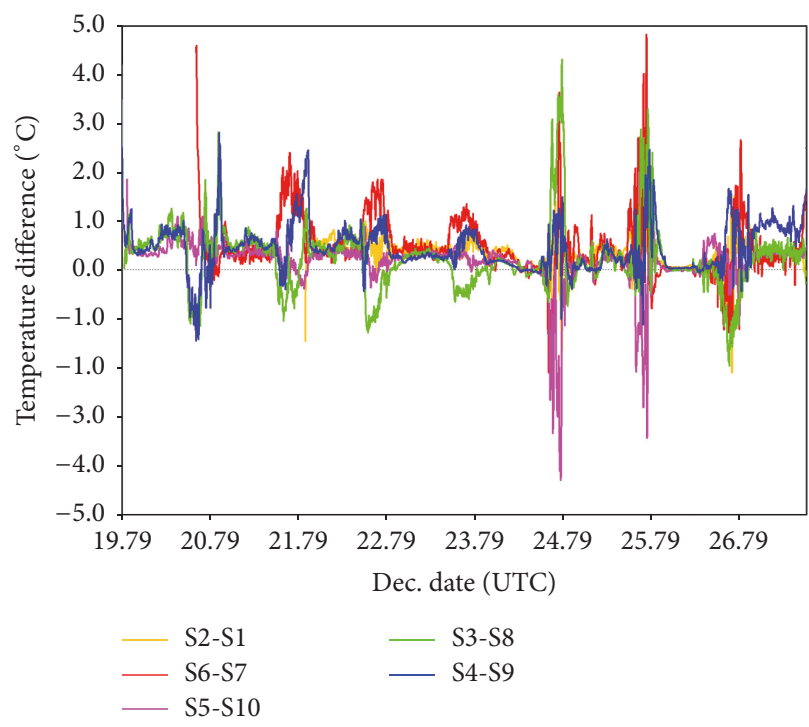

(a)

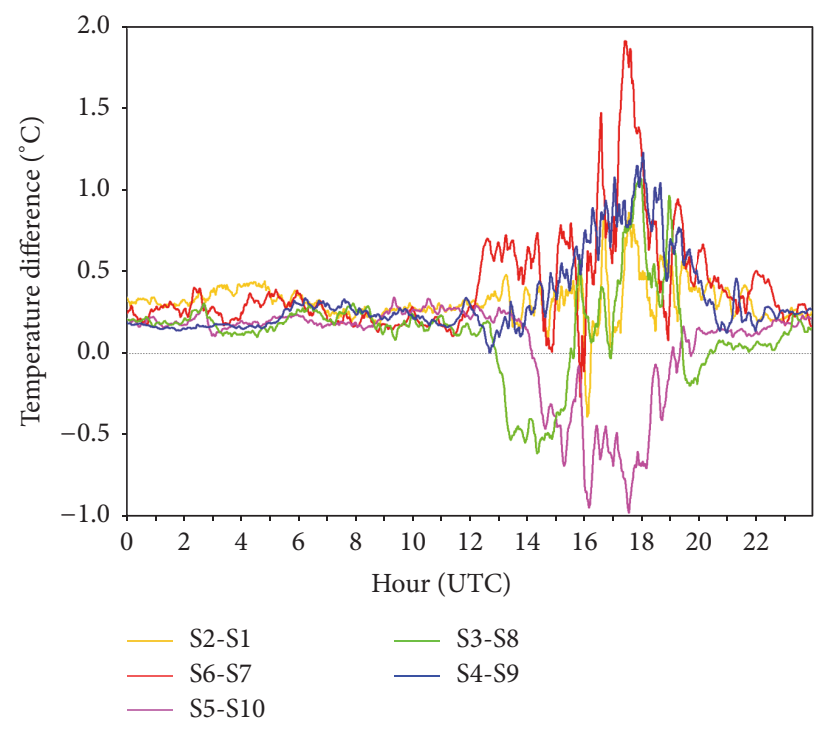

(b)

Figure 5: (a) Temperature differences between $2 \mathrm{~m}$ and $1 \mathrm{~m}$ above the glacier surface (19-26 March 2015), as recorded by the Tinytags at the five glacier stations (Figure 1); and (b) mean daily profiles (22-26 March 2015) of the data shown in Figure 5(a).

TABLE 6: Daily and mean daily (22-26 March 2015) temperatures $\left({ }^{\circ} \mathrm{C}\right)$ for all ten Tinytag sensors (1-m and 2-m elevation at five sites) based on 1-min data.

\begin{tabular}{|c|c|c|c|c|c|c|}
\hline & $22 \mathrm{Mar}$ & $23 \mathrm{Mar}$ & $24 \mathrm{Mar}$ & 25 Mar & $26 \mathrm{Mar}$ & Mean daily \\
\hline \multicolumn{7}{|c|}{ 2-m Tinytags } \\
\hline S2 & 4.6 & 4.2 & 2.1 & 1.3 & 0.2 & 2.5 \\
\hline S6 & 2.7 & 2.4 & 1.6 & 0.3 & -1.6 & 1.1 \\
\hline S5 & 0.0 & -0.3 & -0.4 & -1.6 & -3.9 & -1.2 \\
\hline S3 & 0.0 & -0.1 & 0.1 & -1.1 & -3.9 & -1.0 \\
\hline S4 & -2.3 & -2.5 & -3.3 & -3.8 & -6.1 & -3.6 \\
\hline \multicolumn{7}{|c|}{ 1-m Tinytags } \\
\hline S1 & 4.1 & 3.8 & 2.0 & 0.9 & 0.1 & 2.2 \\
\hline S7 & 2.0 & 1.8 & 1.4 & -0.1 & -1.8 & 0.6 \\
\hline S10 & -0.3 & -0.6 & -0.1 & -1.5 & -4.0 & -1.3 \\
\hline S8 & 0.0 & -0.1 & -0.3 & -1.5 & -3.7 & -1.2 \\
\hline S9 & -2.9 & -2.8 & -3.4 & -4.2 & -6.4 & -3.9 \\
\hline
\end{tabular}

for several hours in mid-afternoon, reflecting rapid changes in the boundary-layer profile and energy exchanges between the atmosphere and surface: this effect was most marked on 24 and 25 March-a time of more unsettled weather conditions, lower solar radiation, and more variable wind (Figure 3).

4.4. Analysis of High-Frequency (1-min) Temperature and Lapse Rate Data. In this section we carry out a more detailed analysis of the 1-min data from the Tinytags, which are presented in Figures 6-8. Daily mean and mean daily (22-26 March 2015) temperatures for all ten Tinytag sensors (1-m and 2-m elevation at five sites) are reported in Table 6, and daily mean and mean daily lapse rates between various pairs of Tinytags are given in Table 7. Near-surface air temperature lapse rates for the full elevation profile (S4-S2 at 2-m and
S9-S1 at 1-m height above the surface) were on average $\sim 1.5-2.0^{\circ} \mathrm{C} \mathrm{km}^{-1}$ lower on 24 and 25 March than the other days. This was during the unsettled weather period when relative humidity (as indicated by DGA) was much higher, indicating a near-saturated air mass. Since saturated air cools at a lower rate as it rises than nonsaturated air (as latent heat is released to its surroundings), this may explain the smaller lapse rates measured on 24/25 March. Although here we are looking at the near-surface lapse rate of the glacier surface rather than the free-air lapse rate of a rising air parcel, these two lapse rates can be related. The smallest daily mean lapse rates of $-3.1^{\circ} \mathrm{C} \mathrm{km}^{-1}$ and $-3.3^{\circ} \mathrm{C} \mathrm{km}^{-1}$ are seen for $\mathrm{S} 6-\mathrm{S} 2$ and S7-S1 (both are Stations 4 and 5) on 24 March (Table 7). This more moderate lapse rate on the lower reaches of the glacier may also be related to changes in the surface energy balance under more cloudy, humid weather conditions. The 
TABLE 7: Daily and mean daily lapse rates $\left({ }^{\circ} \mathrm{C} \mathrm{km}^{-1}\right)$ between various pairs of Tinytag sensors based on 1-min data.

\begin{tabular}{|c|c|c|c|c|c|c|}
\hline & $22 \mathrm{Mar}$ & $23 \mathrm{Mar}$ & $24 \mathrm{Mar}$ & 25 Mar & $26 \mathrm{Mar}$ & Mean daily \\
\hline \multicolumn{7}{|c|}{ 2-m Tinytags } \\
\hline S4-S2 & -8.5 & -8.5 & -6.6 & -6.3 & -7.7 & -7.4 \\
\hline S3-S2 & -8.8 & -8.8 & -3.9 & -4.8 & -8.0 & -6.7 \\
\hline S5-S2 & -10.5 & -10.5 & -5.7 & -6.5 & -9.2 & -8.4 \\
\hline S6-S2 & -10.9 & -10.9 & -3.1 & -5.9 & -10.3 & -8.1 \\
\hline S4-S6 & -7.8 & -7.8 & -7.6 & -6.4 & -7.0 & -7.3 \\
\hline S3-S6 & -7.7 & -7.7 & -4.4 & -4.2 & -6.9 & -6.0 \\
\hline S5-S6 & -10.2 & -10.2 & -7.4 & -7.0 & -8.5 & -8.6 \\
\hline S4-S5 & -6.2 & -6.2 & -7.7 & -6.0 & -5.9 & -6.3 \\
\hline S4-S3 & -8.0 & -8.0 & -11.2 & -9.0 & -7.1 & -8.7 \\
\hline \multicolumn{7}{|c|}{ 1-m Tinytags } \\
\hline S9-S1 & -8.5 & -8.5 & -6.6 & -6.2 & -7.9 & -7.5 \\
\hline S8-S1 & -8.0 & -8.0 & -4.5 & -4.7 & -7.4 & -6.4 \\
\hline S10-S1 & -9.9 & -9.9 & -4.7 & -5.3 & -9.3 & -7.8 \\
\hline S7-S1 & -11.9 & -11.9 & -3.3 & -5.9 & -10.6 & -8.6 \\
\hline S9-S7 & -7.6 & -7.6 & -7.6 & -6.3 & -7.2 & -7.1 \\
\hline S8-S7 & -5.9 & -5.9 & -5.0 & -4.1 & -5.7 & -5.2 \\
\hline S10-S7 & -8.5 & -8.5 & -5.7 & -4.9 & -8.3 & -7.2 \\
\hline S9-S10 & -6.9 & -6.9 & -8.9 & -7.2 & -6.3 & -7.1 \\
\hline S9-S8 & -9.4 & -9.4 & -10.4 & -8.8 & -8.8 & -9.3 \\
\hline
\end{tabular}

lapse rates on the upper reaches on the glacier (S4-S3 and S9-S8) are below $-10^{\circ} \mathrm{C} \mathrm{km}^{-1}$, which are some of the steepest lapse rates recorded. Figure 6(a) is a much highertime resolution version of the temperature data in Figure 4(a) (but does not include DGA data). Although the two graphs look rather similar, Figure 6(a) shows striking short-term (minutes-timescale) temperature fluctuations that are hidden in Figure 4(a). For example, a $\sim 4^{\circ} \mathrm{C}$ temperature drop at S2 is clearly visible just before the daily temperature peak on 26 March in Figure 6(a) is almost completely smoothed out in Figure 4(a); a similar feature is seen in the S1 profile in Figure 6(b).

These short-term temperature fluctuations contribute to brief blips in the lapse rates shown in Figure 7 of as high as $\pm 30-50^{\circ} \mathrm{C} \mathrm{km}^{-1}$ for several minutes, generally in the early afternoons: these are most marked for the S6-S2 and S7S1 (Stations 4 and 5) subprofile on the lower part of the glacier and are much more modest $\left(\sim 0--20^{\circ} \mathrm{C} \mathrm{km}^{-1}\right)$ for the full vertical profile (S4-S2 and S9-S1, Stations 1 and 5). Figure 8 shows the mean daily lapse rate profiles for various pairs of sites (e.g., between 2-m Tinytags in Figures 8(a) and 8(c) and 1-m Tinytags in Figures 8(b) and 8(d)). Figure 8(e) shows lapse rates for both the 2-m and 1-m Tinytags for the upper half of the glacier. Large fluctuations in the lapse rates in the early mid-afternoon (local time) dominate all the plots in Figure 8, in contrast to relatively stable lapse rates at other times of the day. The temporary lapse rate reversal from negative values to positive values for the lower two sites, best shown here for the S6-S2 2-m profile (Figure 8(a)), has been remarked on (Section 4.2) but is now shown in much more detail-especially regarding the extreme values reached-based on the 1-min Tinytag data. Here, for S6-S2, we see a spike going up to $+5^{\circ} \mathrm{C} \mathrm{km}^{-1}$ (Figure $8(\mathrm{a})$ ), which, because it occurred between hours, is not apparent in the mean hourly lapse rate data in Table 3 . The relatively large fluctuations in the afternoon lapse rates tend to be greater for the Tinytags at $2 \mathrm{~m}$ compared with those at $1 \mathrm{~m}$ (Figures $8(\mathrm{a})-8(\mathrm{~d})$ ), indicating an atmospheric influence with stronger decoupling from the surface at the higher height.

4.5. Comparison of Tinytag and LogTag Temperature Data. The main Tinytag temperature data were compared with a supplementary LogTag temperature sensor that was also included in each screen. Mean temperature differences of LogTag minus Tinytag temperatures for 22-26 March are shown in Table 8 and Figure S2, and the whole time series are in Figure S1 (Supplementary Material, available online at https://doi.org/10.1155/2017/6581537). For nine out of ten instrument sites, these differences are within $\pm 0.3^{\circ} \mathrm{C}$, with an overall mean difference of $+0.2^{\circ} \mathrm{C}$. This small temperature difference was analyzed by time of day and was found to be greatest at $+0.5^{\circ} \mathrm{C}$ for 12:00-15:00 GMT, that is, mid-late morning local time, and least at $0.0^{\circ} \mathrm{C}$ at 18:00-21:00 GMT. These differences are mainly within instrument error but the LogTag mid-late morning warm bias was accentuated at a couple of sites, that is, for $\mathrm{S} 7$ was $+1.0^{\circ} \mathrm{C}$ at 12:00-15:00, $+1.3^{\circ} \mathrm{C}$ at $15: 00-18: 00$, and $+0.9^{\circ} \mathrm{C}$ at $18: 00-21: 00$. The S9 LogTag warm bias was $+0.7^{\circ} \mathrm{C}$ at $12: 00-15: 00$ and $+0.8^{\circ} \mathrm{C}$ at 15:00-18:00. These slightly larger temperature differences at a couple of sites are either on the threshold of or slightly exceed instrument error and show an occasional tendency for the LogTags to give slightly higher temperatures than 


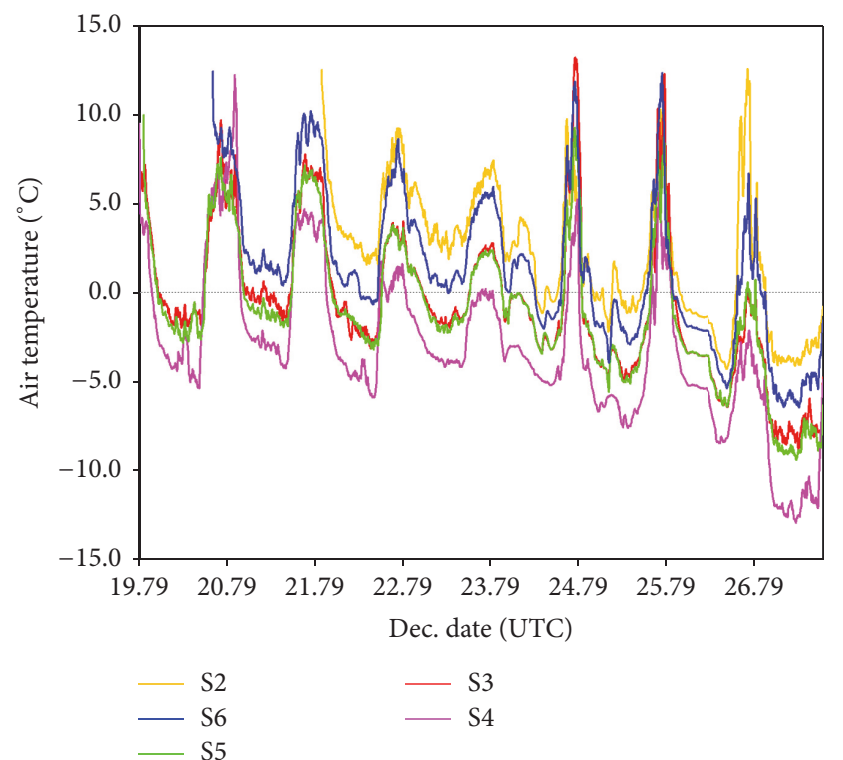

(a)

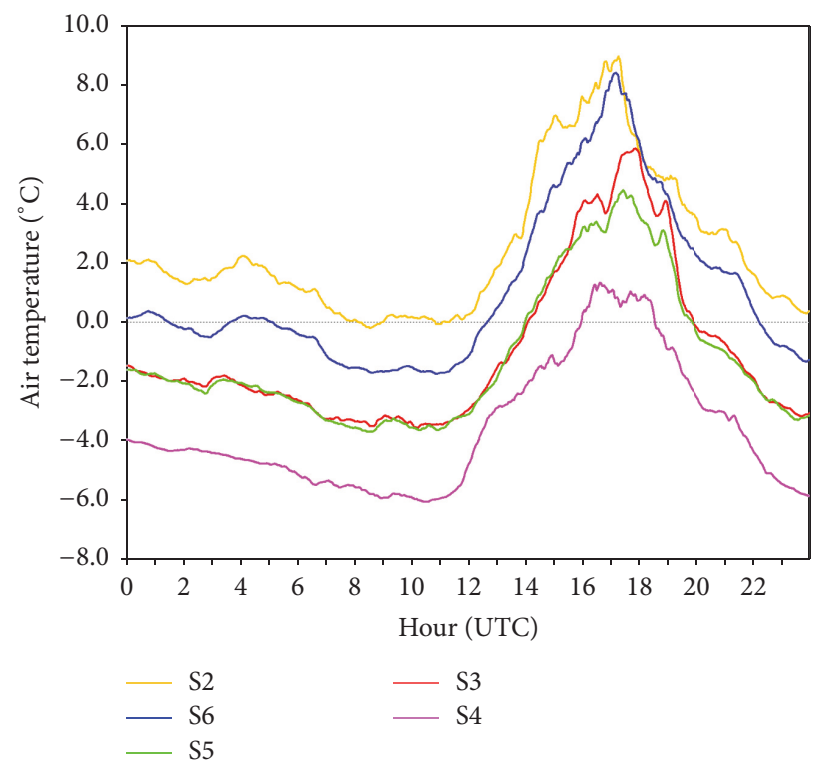

(c)

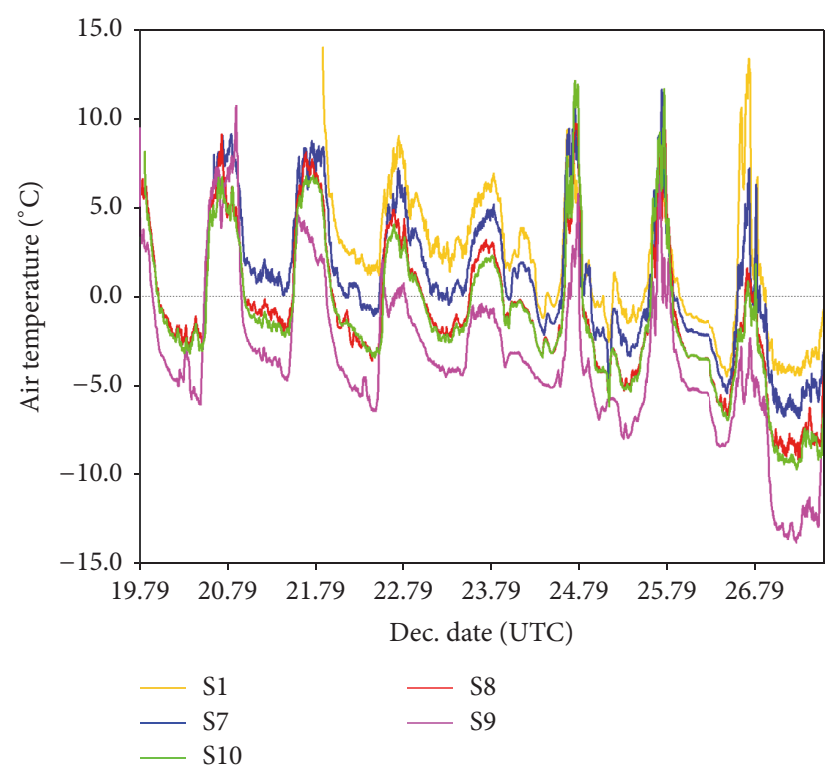

(b)

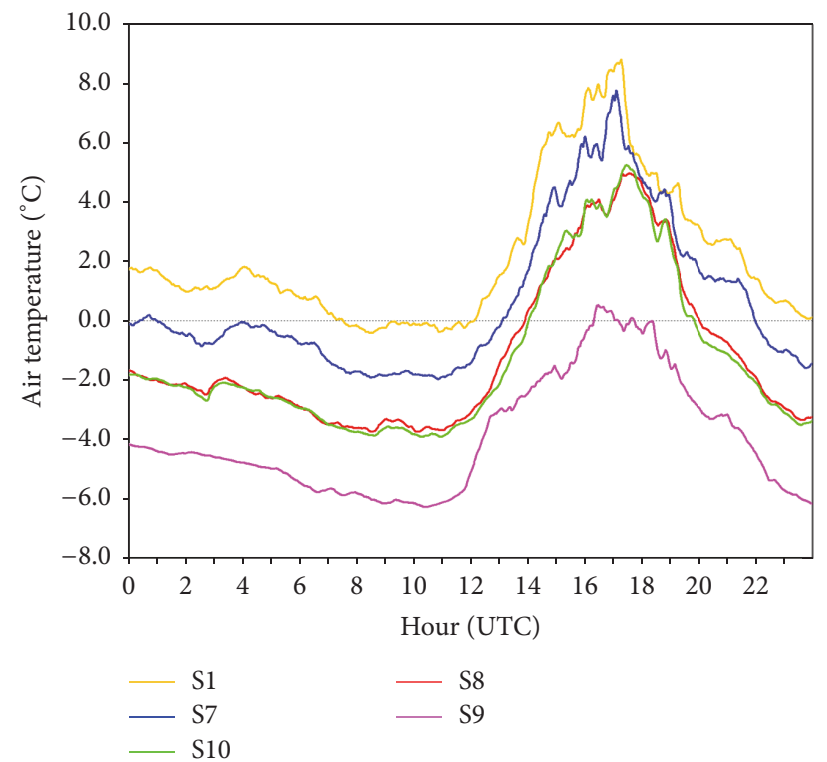

(d)

FIGURE 6: (a) 2-m surface air temperature profiles at the Tinytag sensors S2, S6, S5, S3, and S4 (moving progressively up the glacier), based on 1-min data; (b) 1-m surface air temperature profiles at the Tinytag sensors S1, S7, S10, S8, and S9 (moving progressively up the glacier), based on 1-min data; (c) mean daily 2-m surface air temperature profiles (22-26 March 2015) for the same stations/sensors as in Figure 6(a); and (d) mean daily 1-m surface air temperature profiles (22-26 March 2015) for the same stations/sensors as in Figure 6(b).

the Tinytags around midday. However, this small difference is apparently spatially random and not systematic across all sites. Figures S1 and S2, respectively, show comparisons of the Tinytag and LogTag temperature time series and mean daily temperature cycles, showing generally very good agreement at all sites. This very good agreement between the two independent sets of instruments, in addition to the absolute calibration procedure for the Tinytags described above, gives us high confidence in our results regarding nearsurface glacier temperature lapse rate values and changes.

\section{Summary and Conclusions}

Our results show that near-surface lapse rates on Glacier Gamma were generally greater under clear/sunny weather conditions-especially in early afternoon-and decreased during a period of more unsettled, cloudy weather later on in the fieldwork, displaying similar trends to those reported for a mountainous region in southcentral Idaho [19]. Temperatures at $1-\mathrm{m}$ and $2-\mathrm{m}$ heights above the surface are generally similar, within $0.5^{\circ} \mathrm{C}$, but occasionally vary by as much as $\pm 4^{\circ} \mathrm{C}$, depending on changes in the surface energy budget 


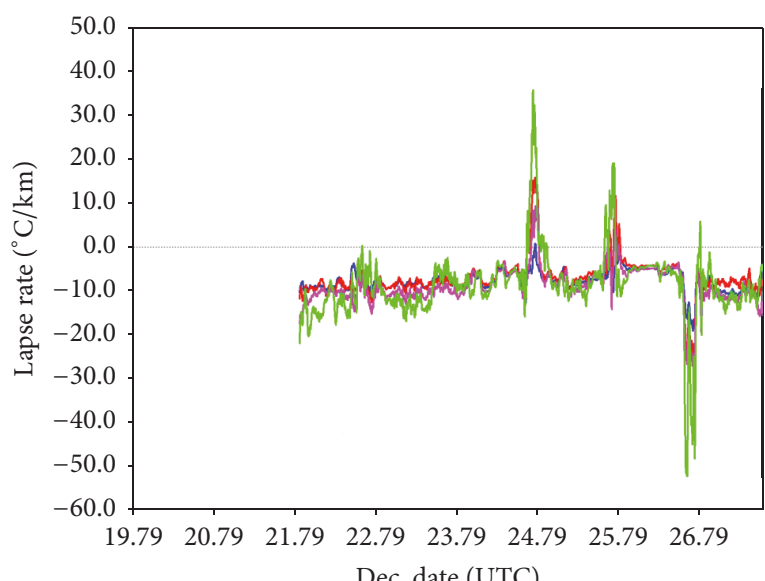

Dec. date (UTC)

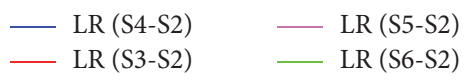

(a)

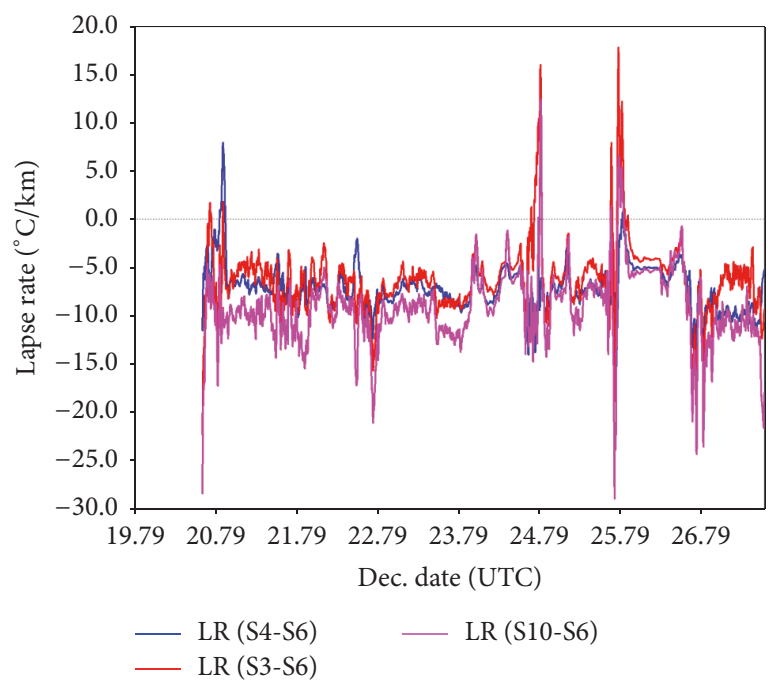

(c)

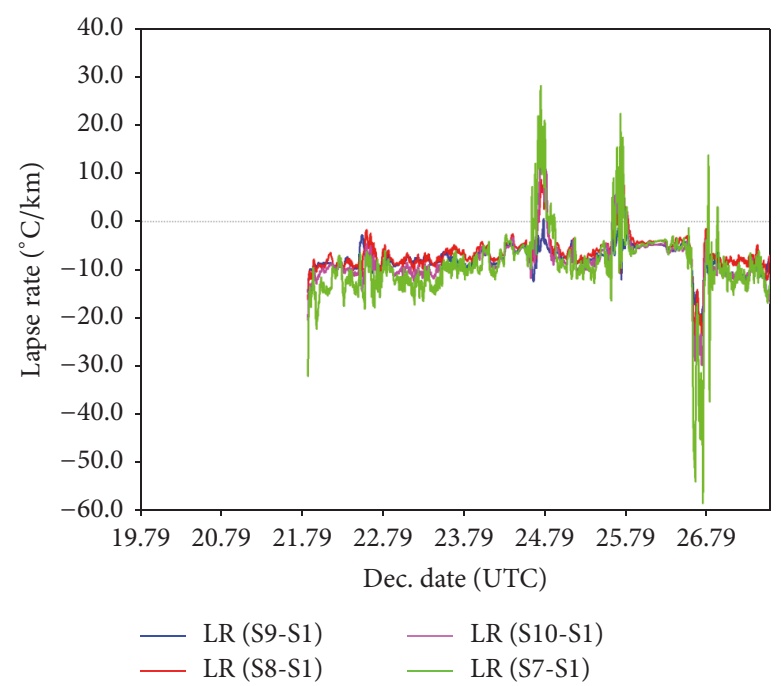

(b)

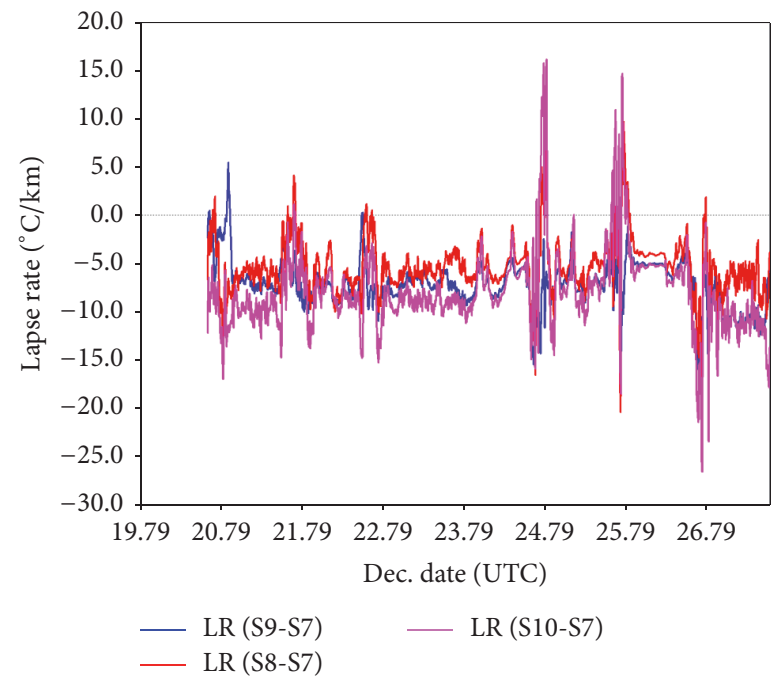

(d)

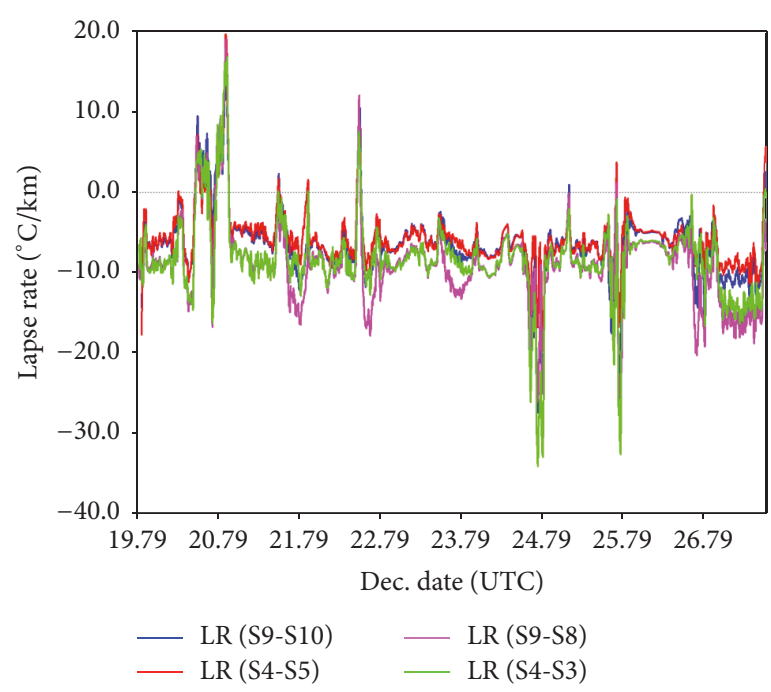

(e)

Figure 7: Near-surface glacier lapse rate variations over time, at 2-m height above the glacier surface, based on 1-min Tinytag temperature data. Different base stations (Figure 1) are used as follows: (a) S2/Station 5 (near the bottom of the glacier); (b) S1/Station 5; (c) S6/Station 4; (d) S7/Station 4; and (e) lapse rates are for the upper half of the glacier (base Stations 2 and 3). 


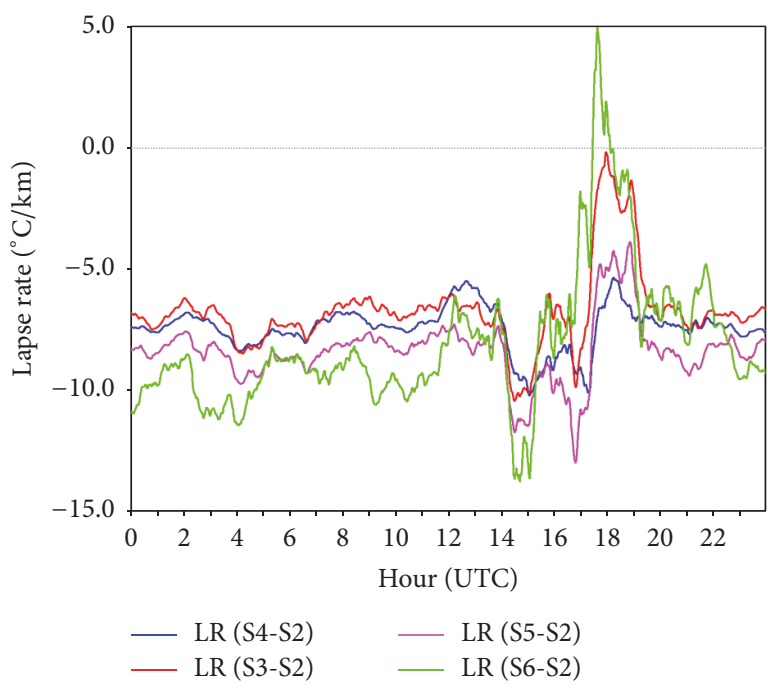

(a)

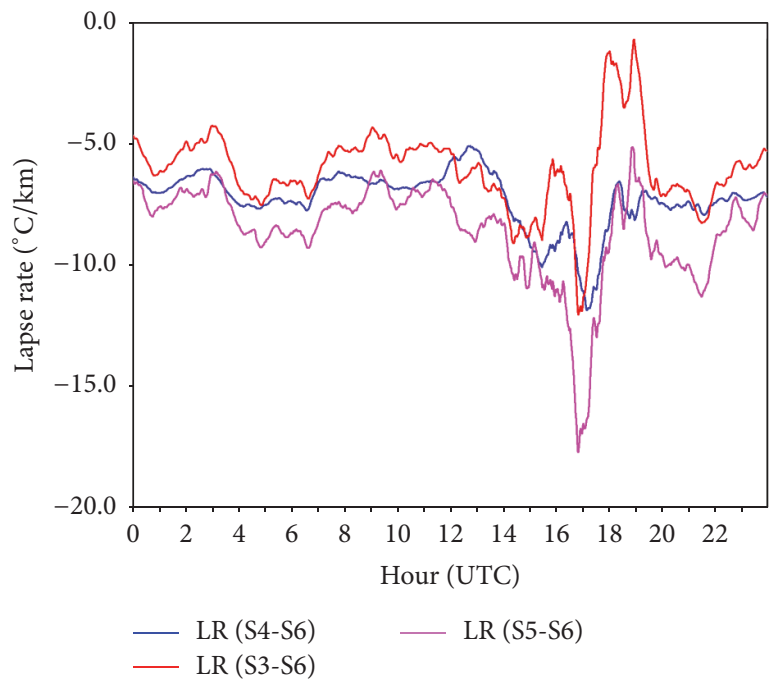

(c)

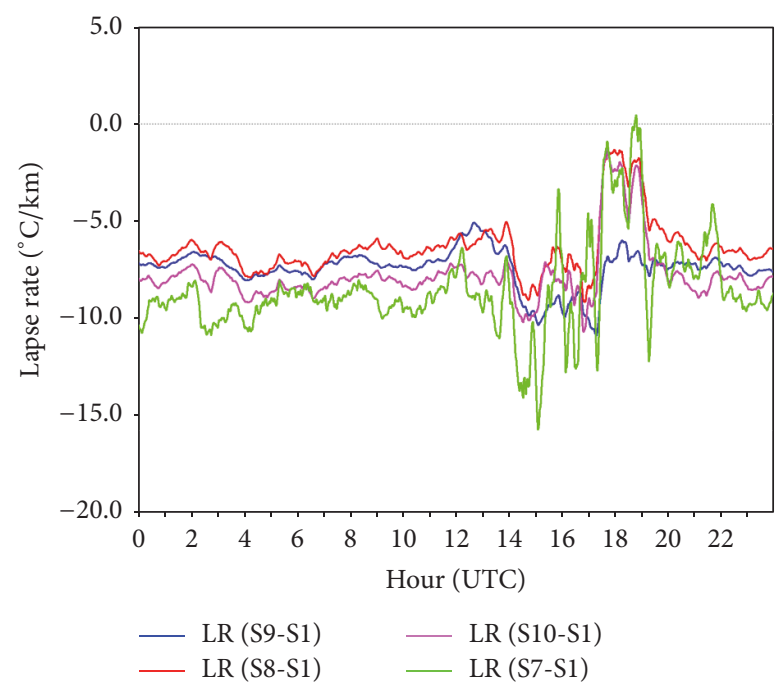

(b)

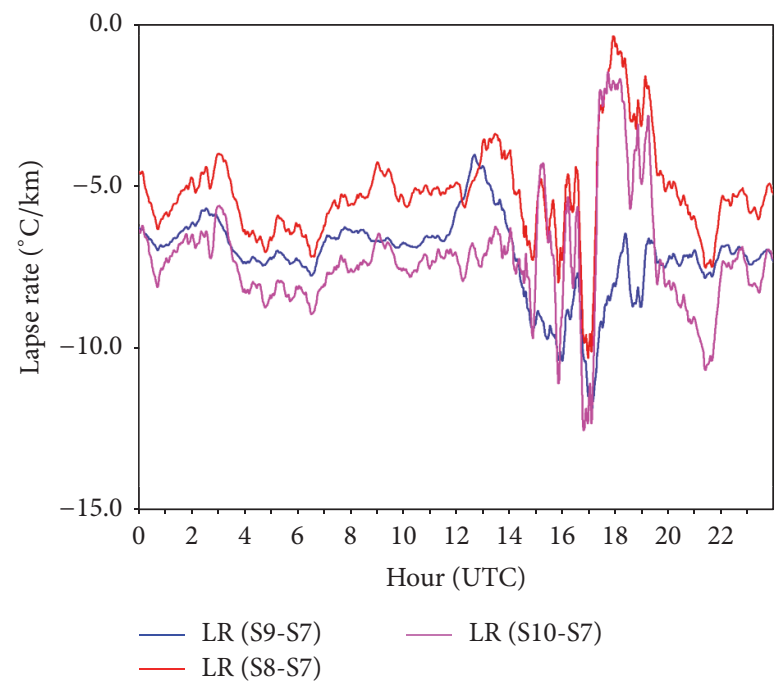

(d)

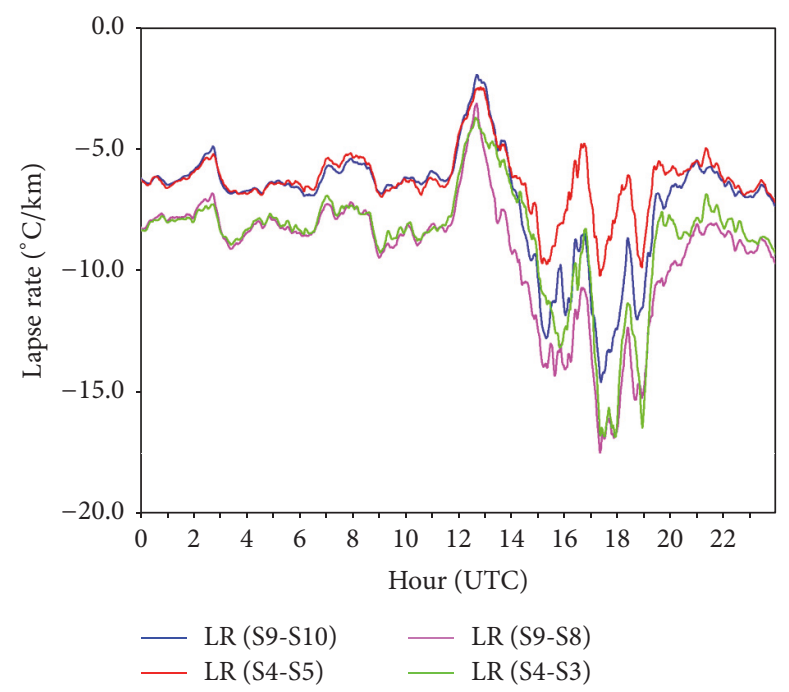

(e)

FIGURE 8: Mean daily profile (22-26 March 2015) of lapse rate data (a) between Station S2 and other stations; (b) between Station S1 and other stations; (c) between Station S6 and other stations; (d) between Station S7 and other stations; and (e) between different stations. 
TABLE 8: A comparison of mean temperatures and the spread of temperature values (standard deviation: ST DEV) $\left({ }^{\circ} \mathrm{C}\right)$ recorded by LogTag and Tinytag instruments, based on 2-min data for 22-26 March, 2015.

\begin{tabular}{|c|c|c|c|c|c|}
\hline & $\begin{array}{c}\text { LogTag } \\
\text { mean } \\
\left({ }^{\circ} \mathrm{C}\right)\end{array}$ & $\begin{array}{c}\text { Tinytag } \\
\text { mean } \\
\left({ }^{\circ} \mathrm{C}\right)\end{array}$ & Mean temperature difference (LogTag-Tinytag) & $\begin{array}{l}\text { LogTag } \\
\text { ST DEV }\end{array}$ & $\begin{array}{l}\text { Tinytag } \\
\text { ST DEV }\end{array}$ \\
\hline \multicolumn{6}{|c|}{ 2-m Tinytags } \\
\hline S2 & 2.7 & 2.5 & 0.2 & 2.5 & 2.4 \\
\hline S6 & 1.2 & 1.0 & 0.1 & 2.6 & 2.7 \\
\hline S5 & -1.1 & -1.2 & 0.1 & 2.4 & 2.3 \\
\hline S3 & -1.2 & -1.0 & -0.2 & 2.2 & 2.6 \\
\hline S4 & -3.5 & -3.6 & 0.1 & 2.3 & 2.1 \\
\hline \multicolumn{6}{|c|}{ 1-m Tinytags } \\
\hline S1 & 2.3 & 2.2 & 0.2 & 2.3 & 2.4 \\
\hline S7 & 1.2 & 0.6 & 0.5 & 2.9 & 2.5 \\
\hline S10 & -1.3 & -1.3 & 0.0 & 2.3 & 2.6 \\
\hline S8 & -0.9 & -1.1 & 0.3 & 2.5 & 2.6 \\
\hline S9 & -3.6 & -3.9 & 0.3 & 2.2 & 2.0 \\
\hline
\end{tabular}

and in the ambient meteorological conditions. This makes it critical to document at what height temperatures are being recorded in any study of high-resolution glacier meteorology (most such studies do not measure air temperature at multiple heights). Our relatively low-cost Tinytag network was able to resolve these vertical temperature changes, as well as spatial/elevational changes in temperatures and lapse rates, at the 1-min timescale, in a dataset that is rarely available for whole glaciers, let alone a glacier in South America or Chile. A natural extension of this study could use suitably mounted and shielded Tinytags to acquire temperature data over the course of 6-12 months, albeit at a slightly decreased sampling time resolution (e.g., 15-30 min), due to the large Tinytag logger capacity (32,000, number of readings). This will provide a better understanding of the monthly, seasonal, and higher-time-resolution variabilities in lapse rates, since most models use linear LR assumptions on mean monthly to annual scales. Another consequence of our findings is that lapse rates-especially in daytime-can be highly spatially and temporally variable (at the 1-min to 1-hour timescale) across a small glacier, and therefore computer models of glacier melt can benefit significantly through having this kind of high-resolution information on surface air temperature lapse rates.

Moreover, we suggest that the assumption of linear lapse rates in glacier melt models appears not to be valid, at least on the subhourly timescale, and meteorological monitoring of a glacier should ideally include multiple temperature loggers along the vertical profile to capture these spatial/temporal inhomogeneities. Therefore, the kind of data here-especially if extended to longer time periods and/or more glaciers-can be used in a sensitivity study to help trial and develop glacier melt models as well as for improving understanding of glacier meteorology and glacier interaction with climate change.

\section{Conflicts of Interest}

The authors declare that they have no conflicts of interest.

\section{Acknowledgments}

The authors acknowledge financial project support from the Chilean government (Fondecyt Regular Project no. 1140172). Also, they thank JSPS (Japan Society for Promote Science) for support, under Project no. S17096. Edward Hanna would like to thank the University of Sheffield for the granting of a sabbatical, which enabled him to join the fieldwork team and pursue this research.

\section{References}

[1] J. Oerlemans, M. Dyurgerov, and R. S. W. Van De Wal, "Reconstructing the glacier contribution to sea-level rise back to 1850," Cryosphere, vol. 1, no. 1, pp. 59-65, 2007.

[2] A. Rabatel, H. Castebrunet, V. Favier, L. Nicholson, and C. Kinnard, "Glacier changes in the Pascua-Lama region, Chilean Andes (29。 S): Recent mass balance and 50 yr surface area variations," Cryosphere, vol. 5, no. 4, pp. 1029-1041, 2011.

[3] J. G. Cogley, “The future of the world's glaciers," in The Future of the World's Climate, A. Henderson Sellers and K. McGuffie, Eds., pp. 197-222, Elsevier, Amsterdam, The Netherlands, 2012.

[4] P. W. Leclercq and J. Oerlemans, "Global and hemispheric temperature reconstruction from glacier length fluctuations," Climate Dynamics, vol. 38, no. 5-6, pp. 1065-1079, 2012.

[5] J. K. Malmros, S. H. Mernild, R. Wilson, R. Fensholt, and J. C. Yde, "Glacier changes in the Rio Olivares catchment, central Chilean Andes, 1955-2013," Journal of Glaciology, vol. 62, no. 232, pp. 391-401, 2016.

[6] S. H. Mernild, G. E. Liston, and C. A. Hiemstra, "Northern hemisphere glacier and ice cap surface mass balance and contribution to sea level rise," Journal of Climate, vol. 27, no. 15, pp. 6051-6073, 2014.

[7] G. Casassa, "Glacier inventory in Chile: current status and recent glacier variations," Annals of Glaciology, vol. 21, pp. 317322, 1995.

[8] J. F. Carrasco, G. Casassa, and J. Quintana, "Changes of the $0^{\circ} \mathrm{C}$ isotherm and the Equilibrium line altitude in central Chile during the last quarter of the 20th century," Hydrological 
Sciences/Journal des Sciences Hydrologiques 50, pp. 933-948, 2005.

[9] S. H. Mernild, G. E. Liston, C. A. Hiemstra, J. K. Malmros, J. C. Yde, and J. McPhee, "The Andes Cordillera. Part I: snow distribution, properties, and trends (1979-2014)," International Journal of Climatology, vol. 37, no. 4, pp. 1680-1698, 2017.

[10] A. Grinsted, "An estimate of global glacier volume," Cryosphere, vol. 7, no. 1, pp. 141-151, 2013.

[11] M. Falvey and R. D. Garreaud, "Regional cooling in a warming world: Recent temperature trends in the southeast Pacific and along the west coast of subtropical South America (1979-2006)," Journal of Geophysical Research Atmospheres, vol. 114, no. 4, Article ID D04102, 2009.

[12] V. Favier, M. Falvey, A. Rabatel, E. Praderio, and D. López, "Interpreting discrepancies between discharge and precipitation in high-altitude area of chile's norte chico region (26-32॰S)," Water Resources Research, vol. 45, no. 2, Article ID W02424, 2009.

[13] M. H. Masiokas, A. Rivera, L. E. Espizua, R. Villalba, S. Delgado, and J. C. Aravena, "Glacier fluctuations in extratropical South America during the past 1000 years," Palaeogeography, Palaeoclimatology, Palaeoecology, vol. 281, no. 3-4, pp. 242-268, 2009.

[14] S. H. Mernild, A. P. Beckerman, J. C. Yde et al., "Mass loss and imbalance of glaciers along the Andes Cordillera to the subAntarctic islands," Global and Planetary Change, vol. 133, pp. 109-119, 2015.

[15] AMAP (2011), "Chapter 7: mountain glaciers and ice caps," in Snow, Water, Ice and Permafrost in the Arctic (SWIPA): Climate Change and the Cryosphere, Chapter 7, p. 538, Arctic Monitoring and Assessment Program (AMAP), Oslo, Norway, 2011.

[16] World Glacier Monitoring Service (WGMS) (2012), Fluctuations of Glaciers 2005-930 2010 (Vol. X), ICSU (WDS)/IUGG (IACS)/UNEP/932 UNESCO/WMO, World Glacier Monitoring Service, Zurich, Switzerland, 2017.

[17] A. Rabatel, B. Francou, A. Soruco et al., "Current state of glaciers in the tropical Andes: A multi-century perspective on glacier evolution and climate change," Cryosphere, vol. 7, no. 1, pp. 81102, 2013.

[18] J. D. Lundquist and D. R. Cayan, "Surface temperature patterns in complex terrain: Daily variations and long-term change in the central Sierra Nevada, California," Journal of Geophysical Research Atmospheres, vol. 112, no. 11, Article ID D11124, 2007.

[19] T. R. Blandford, K. S. Humes, B. J. Harshburger, B. C. Moore, V. P. Walden, and H. Ye, "Seasonal and synoptic variations in nearsurface air temperature lapse rates in a mountainous basin," Journal of Applied Meteorology and Climatology, vol. 47, no. 1, pp. 249-261, 2008.

[20] J. R. Minder, P. W. Mote, and J. D. Lundquist, "Surface temperature lapse rates over complex terrain: lessons from the Cascade Mountains," Journal of Geophysical Research, vol. 115, Article ID D14122, 2010.

[21] M. Pagès and J. R. Miró, "Determining temperature lapse rates over mountain slopes using vertically weighted regression: A case study from the Pyrenees," Meteorological Applications, vol. 17, no. 1, pp. 53-63, 2010.

[22] G. E. Liston and K. Elder, "A meteorological distribution system for high-resolution terrestrial modeling (MicroMet)," Journal of Hydrometeorology, vol. 7, no. 2, pp. 217-234, 2006.

[23] R. C. Harlow, E. J. Burke, R. L. Scott, W. J. Shuttleworth, C. M. Brown, and J. R. Petti, "Derivation of temperature lapse rates in semi-arid south-eastern Arizona," Hydrology and Earth System Sciences, vol. 8, no. 6, pp. 1179-1185, 2004.
[24] DGA., "Estimacion de volumenes de hielo en glaciers de Chile Central," Direction de Aguas. SIT, vol. 264, no. 1, p. 155, 2011.

[25] Z. Yang, E. Hanna, T. V. Callaghan, and C. Jonasson, "How can meteorological observations and microclimate simulations improve understanding of 1913-2010 climate change around Abisko, Swedish Lapland?" Meteorological Applications, vol. 19, no. 4, pp. 454-463, 2012.

[26] N. Pepin, D. Benham, and K. Taylor, "Modeling lapse rates in the maritime uplands of northern England: Implications for climate change," Arctic, Antarctic, and Alpine Research, vol. 31, no. 2, pp. 151-164, 1999. 

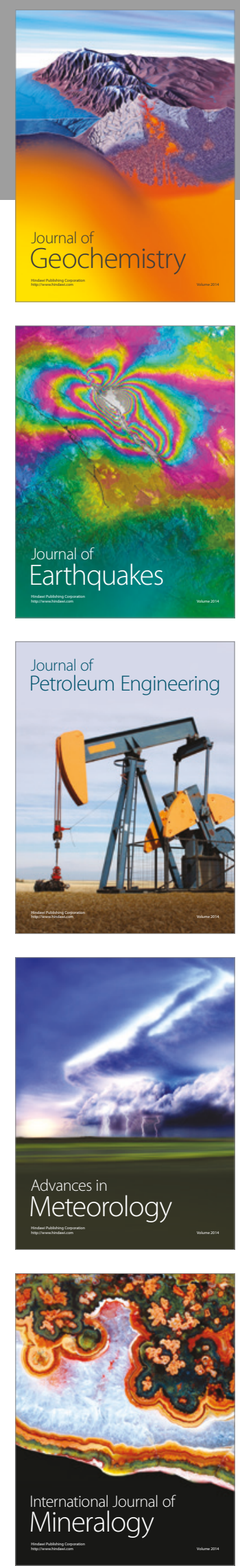
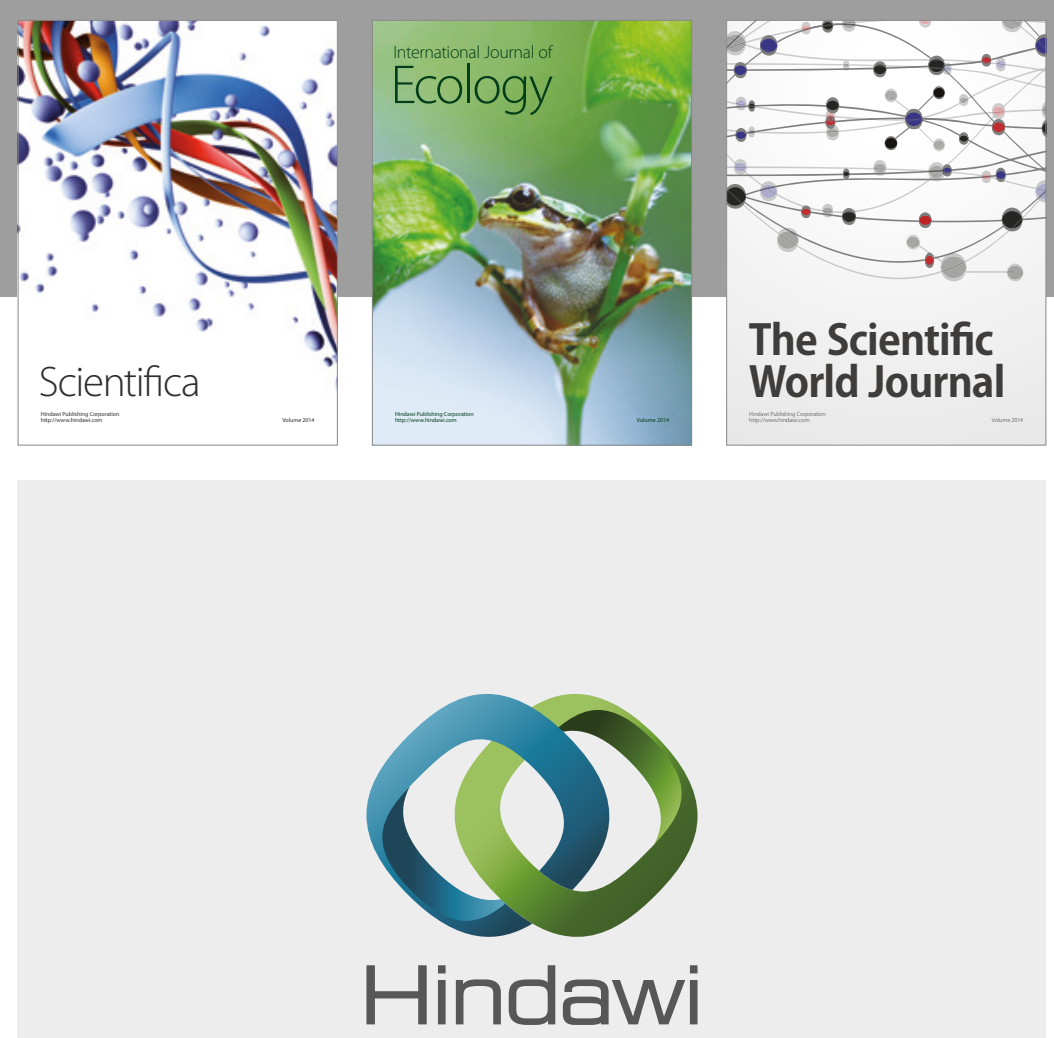

Submit your manuscripts at

https://www.hindawi.com
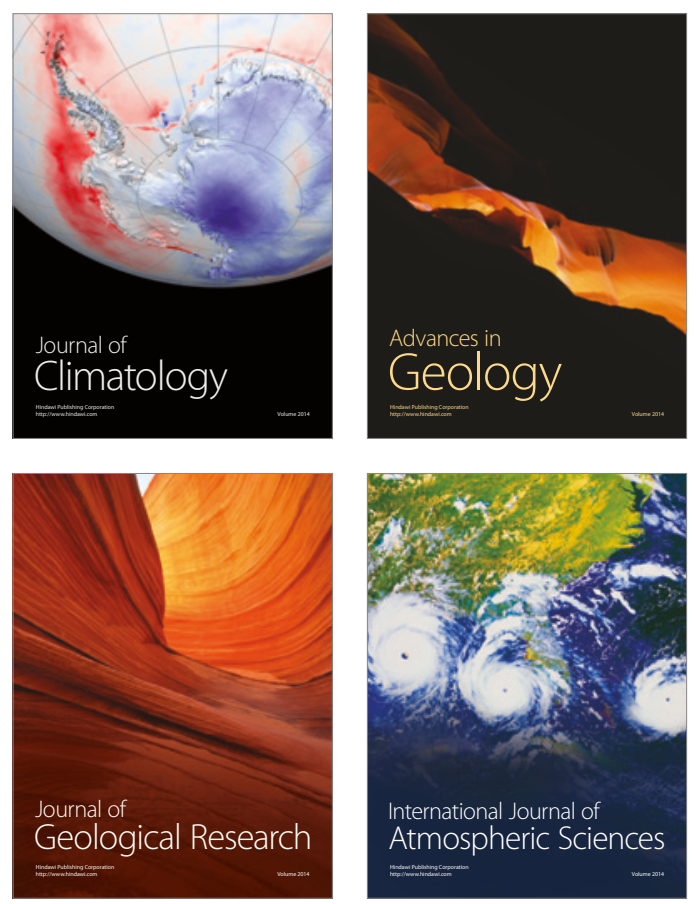

The Scientific

World Journal
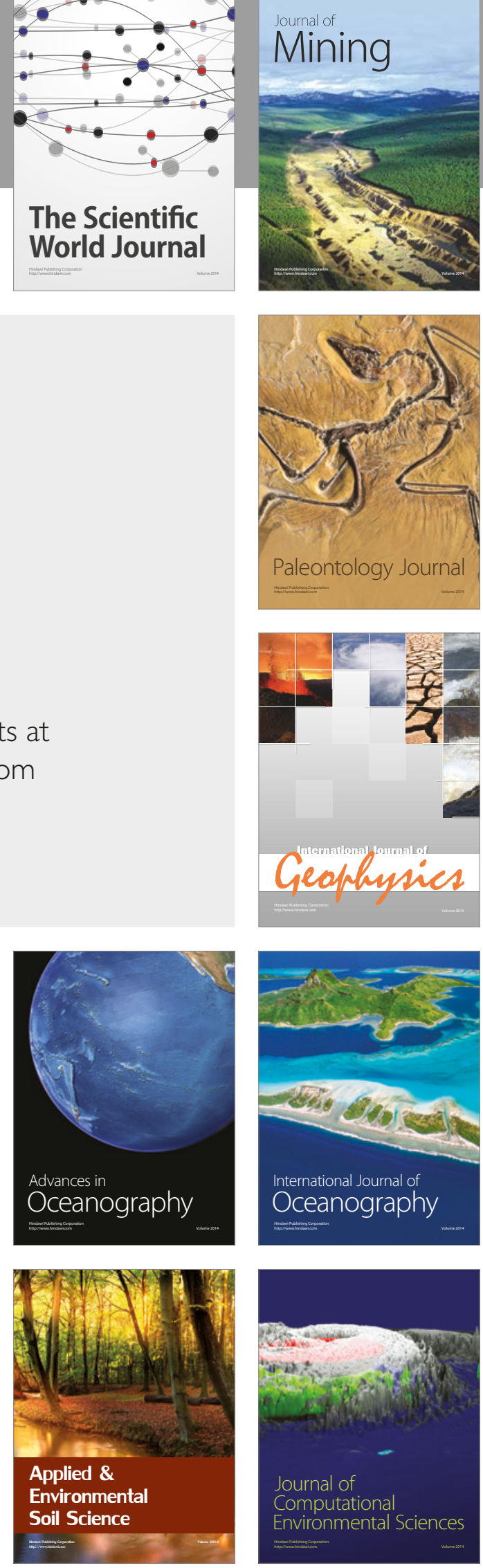